\title{
EI Niño-like conditions and seasonal aridity in the Indo-Pacific Warm Pool during the Younger Dryas
}

\author{
Petter L. Hällberg ${ }^{1}$, Frederik Schenk ${ }^{1,2}$, Kweku A. Yamoah ${ }^{3}$, Xueyuen Kuang ${ }^{4}$, Rienk H. Smittenberg ${ }^{1}$ \\ ${ }^{1}$ Department of Geological Sciences and Bolin Centre for Climate Research, Stockholm University, 106 91, Sweden, \\ $5 \quad{ }^{2}$ Rossby Centre, Swedish Meteorological and Hydrological Institute, 601 76, Sweden, \\ ${ }^{3}$ School of Geography, Earth and Environmental Sciences, University of Birmingham, B15 2TT, UK \\ ${ }^{4}$ School of Atmospheric Sciences, Nanjing University, 210023, China
}

Correspondence to: Petter L. Hällberg (petter.hallberg@geo.su.se)

\begin{abstract}
10 Island South-East Asia (ISEA) is a highly humid region and hosts the world's largest tropical peat deposits. Most of this peat accumulated relatively recently during the Holocene, suggesting a generally drier and/or more seasonal climate during earlier times. Although there is evidence for savanna expansion and drier conditions during the Last Glacial Maximum (LGM, 21 ka $\mathrm{BP})$, the mechanisms behind hydroclimatic changes during the ensuing deglacial period has received much less attention and are poorly understood. Here we use CESM1 climate model simulations to investigate the key drivers behind ISEA climate at

15 the very end of the last deglacial period, at $12 \mathrm{ka} \mathrm{BP}$. A transient simulation (TRACE) is used to track the climate seasonality and orbitally driven change over time during the deglaciation into the Holocene. In agreement with proxy-evidence, CESM1 simulates overall drier conditions at $12 \mathrm{ka} \mathrm{BP}$. More importantly, ISEA experienced extreme seasonal aridity, in stark contrast to the ever-wet modern climate. We identify that the simulated drying and enhanced seasonality at $12 \mathrm{ka} \mathrm{BP}$ is mainly the result of a combination of three factors: 1) large orbital insolation difference between summer and winter in contrast to the

20 LGM and the present day; 2) a stronger winter monsoon caused by a larger interhemispheric thermal gradient in boreal winters; and 3) a major reorganization of the Walker Circulation with an inverted land-sea circulation with a complete breakdown of deep convection over ISEA. The altered atmospheric circulation mean state during winters led to conditions resembling extreme El Niño events in the modern climate and a dissolution of the Inter-Tropical Convergence Zone (ITCZ) over the region. From these results we infer that terrestrial cooling of ISEA and at least a seasonal reversal of land-sea circulation likely played a major role in delaying tropical peat formation until at least the onset of the Holocene period.
\end{abstract}


https://doi.org/10.5194/cp-2021-164

Preprint. Discussion started: 16 December 2021

(c) Author(s) 2021. CC BY 4.0 License.

\section{(c) (1)}

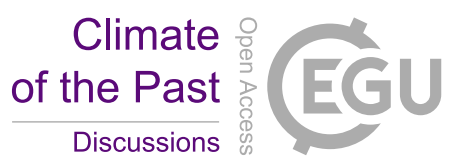

\section{Introduction}

The Indo-Pacific Warm Pool (IPWP) is the world's largest region with sea-surface temperatures permanently above $28{ }^{\circ} \mathrm{C}$. This 'heat and steam engine of the globe', is a major source of atmospheric deep convection and heat flux in the tropics and plays a key role for monsoon systems that directly affect approximately half of the global population (De Deckker, 2016; Chabangborn et al., 2018). Currently, the IPWP is undergoing rapid change and has doubled in size during 1981-2018

35 compared to 1900-1980, and the growth rate is accelerating (Roxy et al., 2019). The IPWP region is highly interconnected to interhemispheric changes through latitudinal shifts of the Intertropical Convergence Zone (ITCZ) and monsoon systems as well as to zonal variations of the Walker Circulation, in particular the El Niño Southern Oscillation (ENSO) over the Pacific Ocean. Located in the central IPWP, Island South-East Asia (ISEA) is wet year-around, hosting tropical rainforests and peat swamp forests (Beck et al., 2018; Malhi and Wright, 2004). Based on climate simulations, it is very likely that rainfall

40 variability will increase in the future under an expanding IPWP and enhanced ENSO variability (Grothe et al., 2020; IPCC, 2021; Wengel et al., 2021). Increasing rain variability in the context of amplified ENSO modes may enhance the risk for seasonal droughts and forest fires in today's ever-wet tropical rain forests. These changes may further weaken the small hydrological cycle of these ecosystems potentially turning carbon sinks into carbon sources under global warming. In this context, it is noteworthy that most of the peatlands and rain forests of ISEA are rather young and became established only

45 during the early to mid-Holocene (Dommain et al., 2014). Whether this rather young age is due to a generally drier climate prior to the Holocene, or rather due to changes in precipitation variability or seasonality, remains a challenging research question.

Stronger ENSO variability has been proposed during the deglaciation ( 16-11.7 thousand years before present; ka BP)

50 (Clement et al., 1999; Koutavas and Joanides, 2012; Sadekov et al., 2013), and the deglacial period climate seasonality can thus be studied as an analogue for projected ENSO changes. Reconstructions from speleothems and other proxies (Dang et al., 2020; Konecky et al., 2016) indicate widespread drier conditions in the IPWP before the early Holocene (ca. 10-11 ka BP). Drier overall conditions coupled with increased ENSO variability suggest that large-scale atmospheric mechanisms were altered during the deglaciation. However, the typically integrated signal derived from proxy-evidence alone does not allow to disentangle the overall climate change signal from potentially more extreme changes on seasonal time-scales.

On a local to regional level, a number of pollen and biomarker-based proxy records, as well as floral and faunal records indicate open grassland/shrub vegetation and drier conditions during the Last Glacial Maximum (LGM: $21 \mathrm{ka}$ BP) and the subsequent deglacial period. This has sparked a debate about to what extent savanna expanded in the region during (potentially seasonally)

60 drier conditions, and a 'Savanna Corridor' hypothesis outlining a savanna biome across the exposed Sunda shelf has been proposed (Bird et al., 2005; Heaney, 1991; Louys and Roberts, 2020; Wurster et al., 2010, 2019) (Fig. 1). However, evidence remains inconclusive for key regions, in part because much of the proposed savanna areas were inundated during deglacial 
https://doi.org/10.5194/cp-2021-164

Preprint. Discussion started: 16 December 2021

(c) Author(s) 2021. CC BY 4.0 License.

(c) (i)

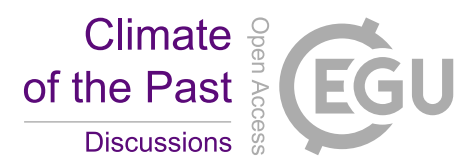

$120 \mathrm{~m}$ sea level rise (Hanebuth et al., 2011). Whether the proposed savanna formed a contiguous "corridor", or if the savanna vegetation was interrupted by a rainforest between Sumatra and Borneo, remains an open question (Cannon et al., 2009;

65 Wurster et al., 2019). The existence of a savanna corridor during the LGM has previously been questioned by Raes et al. (2014) based on rainforest species distribution modelling forced by two climate models. These showed increased precipitation compared to modern climate on north Borneo and on the Sunda shelf (Brady et al., 2013). However, the simulated increase in precipitation is at odds with both a PMIP3 model synthesis of eleven climate model simulations (PMIP3 Synthesis maps, 2014; https://pmip3.lsce.ipsl.fr/), and with cave deposit $\delta^{18} \mathrm{O}$ records in that area (Partin et al., 2007; Wurster et al., 2010), suggesting

70 that their results may be based on a too wet climate model output. The lack of proxy records and a limited understanding about the driving mechanisms for an altered climate state during the deglaciation call for the need of climate modelling experiments to unravel drivers behind such drastic changes.

Although it is well accepted that the Sunda climate was generally drier and colder prior to the Holocene, previous research has mainly focused on the LGM, with much less attention on transient changes during the deglacial period. Also, how this generally drier climate might have been related to seasonality changes rather than just mean changes in precipitation, has received very little attention. The goal of this study is to investigate the seasonal climate evolution in the Sunda region by analyzing climate model simulations, a transient coupled ocean-atmosphere model, and comparing it to available proxy data. We focus here on the period $\sim 12 \mathrm{ka}$ BP known as the Younger Dryas, representing the very end of the deglaciation before the start of the warm and wet Holocene. This enables further insight into the deglacial climate, in a period with different seasonal orbital forcing compared to both the PI and the more studied LGM. In particular, we quantify the length and aridity of the dry season, since these parameters can have a much stronger effect on ecosystems than the total annual precipitation (Malhi and Wright, 2004). We then investigate the large-scale forcings and mechanisms that dominate the deglacial tropical climate on seasonal timescales in comparison to the modern pre-industrial climate. 


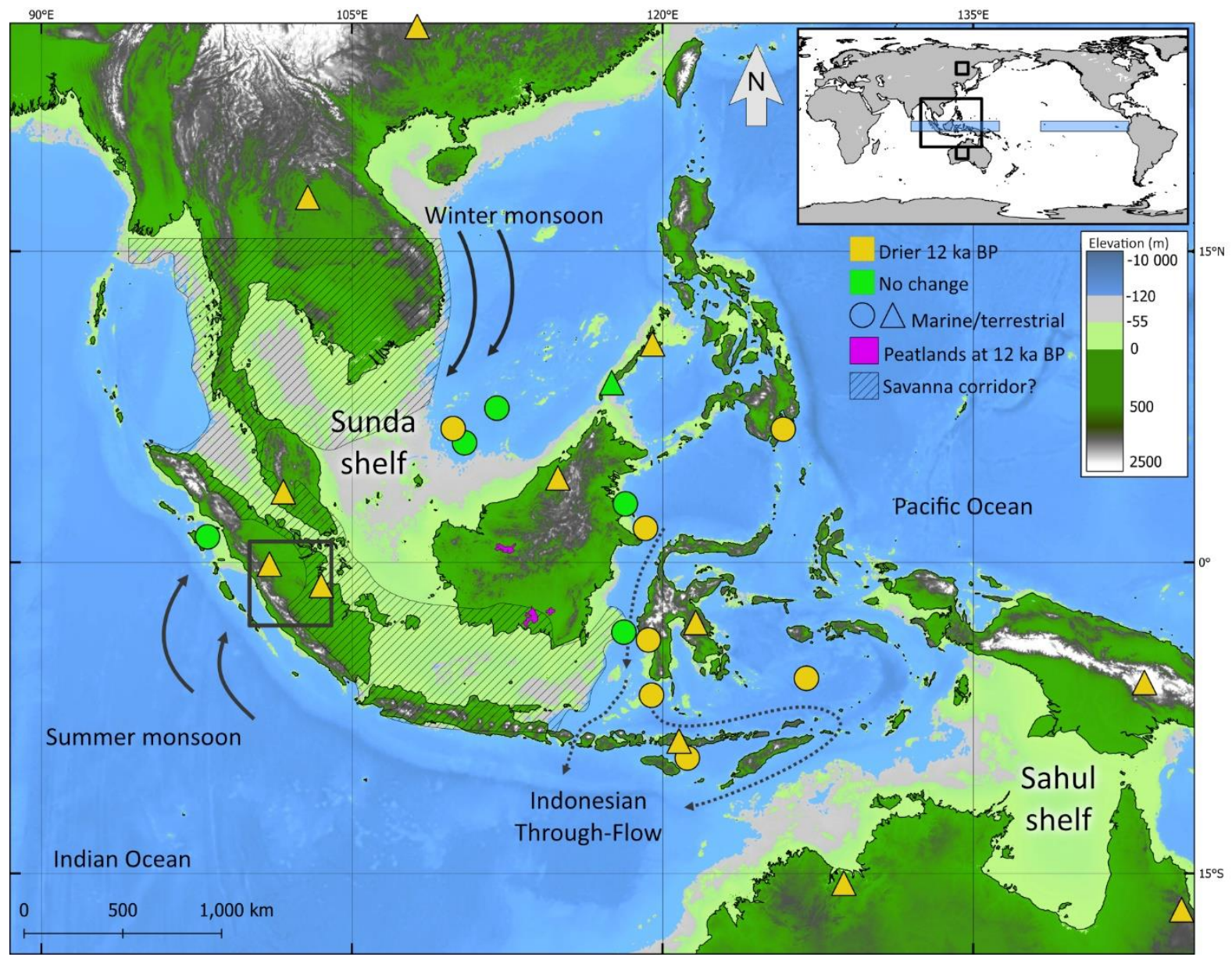

Figure 1: Topographic map of South-East Asia and a compilation of available climate proxy records (supplementary Table 1). Yellow markers indicate drier or more seasonal climate at $12 \mathrm{ka} \mathrm{BP}$ compared to PI, and green indicates no notable difference. Purple areas denote the peatland extent at $12 \mathrm{ka} \mathrm{BP}$ (Dommain et al., 2014). Exposed land due to lower sea level at $12 \mathrm{ka}$ BP shown in light green and in light gray for the LGM. The hatched area indicates the proposed savanna corridor on the Sunda shelf at the LGM (Cannon et al., 2009). Black square on the regional map indicates the area used to track long-term changes in seasonality from TRACE (Fig. 2f, g). Small black squares in the global map inset show the areas used for estimating the thermal gradient over ISEA and blue squares are used for Walker Circulation Index calculations (Fig. 7a).

\section{Materials and methods}

\subsection{Proxy data compilation}

To synthesize the available proxy-evidence for the IPWP region at the end of the deglaciation, we compiled paleoclimatic proxy records based on pollen assemblages, $\delta^{13} \mathrm{C}$ and $\delta^{18} \mathrm{O}$ that spans at least the last $12 \mathrm{kyr}$ (see Table S1). We follow the interpretations of the authors, and $\delta^{13} \mathrm{C}$ is considered to reflect $\mathrm{C} 3 / \mathrm{C} 4$ vegetation abundance, which reflects aridity or climate

100 seasonality, while $\delta^{18} \mathrm{O}$ and $\delta \mathrm{D}$ mainly reflects precipitation amounts. Speleothem $\delta^{18} \mathrm{O}$ records in the Sunda region from Borneo at $4^{\circ} \mathrm{N}$ (Partin et al., 2007), equatorial Sumatra at $0^{\circ} \mathrm{N}$ (Wurtzel et al., 2018) and Java at $8^{\circ} \mathrm{S}$ (Ayliffe et al., 2013) 
https://doi.org/10.5194/cp-2021-164

Preprint. Discussion started: 16 December 2021

(c) Author(s) 2021. CC BY 4.0 License.

\section{(c) (1)}

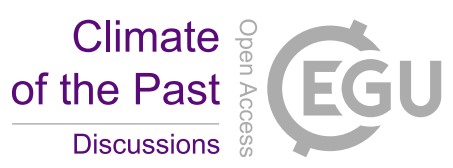

show the overall deglacial transient climate evolution in the region and that regional climate shifts are partly out of phase between north and south hemisphere due to bipolar seesaw mechanisms and the impact from different monsoonal systems (Ayliffe et al., 2013). Greenland ice $\delta^{18} \mathrm{O}$ (NGRIP members, 2004) is shown as a comparison to the Sunda speleothem records to highlight that the deglacial climate transition is similar in terms of timing and direction at polar latitudes and Sunda's tropical latitude. The topographic map data used to outline the modern, $12 \mathrm{ka} \mathrm{BP}$ and LGM coastlines in figures was derived from NOAA's 1-arc minute ETOPO1 present-day elevation dataset (Amante and Eakins, 2009). 12 ka BP sea level was set to -55 $\mathrm{m}$, and LGM sea level was set to - $120 \mathrm{~m}$ compared to current sea level.

\subsection{Climate model simulations}

To investigate the transient change in temperature and precipitation seasonality from the LGM to the present on Sunda, the TraCE21ka simulation data (He, 2011; He et al., 2013; Liu et al., 2009) (hereafter referred to as TRACE) is used. The TRACE simulation was performed with the CCSM3 model developed by NCAR, and is a full-complexity coupled atmosphere-ocean model. For the transient paleoclimate runs, CCSM3 was forced with changes in greenhouse gas concentrations and orbital insolation changes. In addition, continental ice sheets and sea level changes were adjusted over time and the fresh water forcing from melting ice sheets and/or drainage of proglacial lakes was set as described in detail by (He, 2011). The spatial model resolution is T31_gx3, $\left(3.75^{\circ} \times 3.75^{\circ}\right.$ in the atmosphere, $\left.415 \mathrm{~km}\right)$. Here, we analyzed TRACE data in the region from presentday Sumatra, Indonesia, which represents the central Sunda region. We select a location $\left(3^{\circ} \mathrm{S}-1^{\circ} \mathrm{N}, 100^{\circ} \mathrm{E}-104^{\circ} \mathrm{E}\right)$ that is currently land surface to avoid signal variation arising from changing the model surface type from water to land during the deglacial transgression.

Because the transient simulation with TRACE had to be performed at a rather coarse spatial resolution, we additionally analyze a higher resolution snapshot simulation for the Younger Dryas that better represents the regional exposure of today's inundated Sunda shelf. The model setup and boundary conditions used for the higher resolution CESM1.0.5 model simulations of 12.17

$125 \mathrm{ka} \mathrm{BP}$ (hereafter referred to as $12 \mathrm{ka} \mathrm{BP}$ ) have been previously described by Schenk et al. (2018). CESM1 is a newer version of CCSM3 that was used previously for the transient simulations of TRACE. The CESM1 simulation here is based on a coupled atmosphere-land-sea ice model with sea surface temperature and sea ice fraction prescribed from TRACE. The CESM simulation has a horizontal resolution of $0.9^{\circ} \times 1.25^{\circ}(\sim 120 \mathrm{~km})$. Continental ice sheets and corresponding sea level and hence land-sea distribution in CESM1 are based on the ice sheet reconstruction from GLAC-1B (Schenk et al., 2018), a precursor of the PMIP4 ice sheet reconstruction (GLAC-D: Ivanovic et al., 2016). The vegetation cover in the $12 \mathrm{ka} \mathrm{BP}$ simulation was prescribed from the pre-industrial state of CESM1, and kept constant during the simulation. The vegetation on exposed shelf areas was set by nearest-neighbor interpolation to reflect adjacent land areas. To avoid some inconsistencies due to changing surface types when interpolating CESM1 model output onto ancient coast lines, model grid points that were partly sea and partly land, i.e., the coastlines, were masked out from the $12 \mathrm{ka} \mathrm{BP}$ simulation and filled using nearest neighbor interpolation. 
https://doi.org/10.5194/cp-2021-164

Preprint. Discussion started: 16 December 2021

(c) Author(s) 2021. CC BY 4.0 License.

(c) (i)

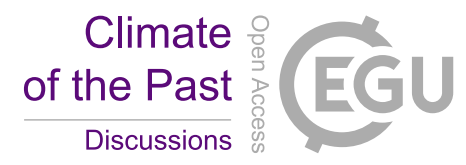

135 The land-sea distribution including coastlines in the $12 \mathrm{ka} \mathrm{BP}$ simulation is shown in Fig. 7c, in which all grid points containing land are greyed out.

\subsection{Analysis}

To compare transient seasonality changes in temperature and precipitation simulated by TRACE, we used insolation data for central Sunda shelf $\left(2^{\circ} \mathrm{N}\right)$ from $20 \mathrm{ka}$ BP to the present (Laskar et al., 2004). To quantify changes and severity of precipitation

140 seasonality, we used $<60 \mathrm{~mm}$ precipitation to define a dry month under tropical conditions following Köppen's classification (Beck et al., 2018). Raes et al. (2014) and Malhi and Wright (2004) used a $100 \mathrm{~mm} / \mathrm{month}$ classification, based on the fact that $100 \mathrm{~mm}$ is close to the monthly evaporation in present-day rainforests. Since $12 \mathrm{ka} \mathrm{BP}$ was colder, leading to lower potential for evapotranspiration, we decided to use the lower value of $60 \mathrm{~mm} / \mathrm{month}$. Given the strong simulated changes, the results are insensitive to the exact definition. As a first order approximation, we estimate the potential thermodynamic contribution

145 of SST cooling on the simulated reductions in total precipitation by calculating a $7 \%$ decrease in total precipitation per Kelvin cooling, based on the Clausius-Clapeyron relation between changes in temperature and potential water vapor uptake by the atmosphere. We then compare this to the simulated change in total precipitation by CESM to separate the thermodynamic contribution from dynamical changes. The temperature gradient in the Asian-Australian monsoon system, responsible for driving the north-south potential strength of the monsoons, was derived between $120-130^{\circ} \mathrm{E}, 20-30^{\circ} \mathrm{S}$ for Australia, and 120 -

$150130^{\circ}$ E, $50-60^{\circ} \mathrm{N}$ for Siberia (boxes on Fig. 1).

We calculated a Walker Circulation Index (WCI) to quantify the strength of the Pacific Walker circulation from monthly mean sea level pressure as the difference in pressure between the IPWP and West Pacific $\left(80^{\circ} \mathrm{E}\right.$ to $160^{\circ} \mathrm{E}, 5^{\circ} \mathrm{S}$ to $\left.5^{\circ} \mathrm{N}\right)$ and the East Pacific $\left(160^{\circ} \mathrm{W}\right.$ to $80^{\circ} \mathrm{W}, 5^{\circ} \mathrm{S}$ to $\left.5^{\circ} \mathrm{N}\right)$, boxes shown in Fig. 1, following Kang et al. (2020). To compare the simulated

155 WCI during PI and $12 \mathrm{ka} \mathrm{BP}$ with observational data, the ERA5 dataset (Hersbach et al., 2020) was used for monthly mean sea level pressure data from 1979 to 2020 to calculate observed changes in the Walker Circulation Index. The average WCI during extreme El Niño years (1983, 1998 and 2015) were compared to the CESM simulations. ERA5 SST data was used from the same El Niño events to compare the SST anomalies during El Niño events for January, which usually is the month with the highest El Niño strength. January SST anomalies in ERA5 data was calculated as the January mean of the entire ERA5 160 dataset (1979-2020) subtracted from the average January SST during the El Niño events in 1983, 1998 and 2015. The simulated SST anomaly at $12 \mathrm{ka} \mathrm{BP}$ compared to PI was calculated as the difference in SST between $12 \mathrm{ka} \mathrm{BP}$ and PI, with the average tropical $\left(23.5^{\circ} \mathrm{S}\right.$ to $\left.23.5^{\circ} \mathrm{N}\right) \mathrm{SST}$ cooling of $2.08 \mathrm{~K}$ between the periods subtracted. This was done to show the relative temperature change within the Pacific Ocean at $12 \mathrm{ka} \mathrm{BP}$. 
https://doi.org/10.5194/cp-2021-164

Preprint. Discussion started: 16 December 2021

(c) Author(s) 2021. CC BY 4.0 License.

(c) (1)

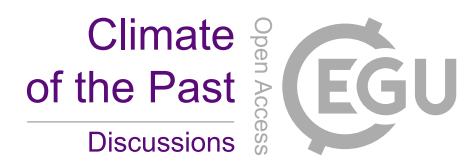

\section{Proxy synthesis in the Sunda region}

The transition from Late Glacial ( 16 to $11.7 \mathrm{ka} \mathrm{BP}$ ) into the current interglacial of the Holocene is marked by significant climatological changes as e.g. reconstructed from cave deposits (e.g., Ayliffe et al., 2013; Partin et al., 2007; Wurtzel et al., 2018) indicating drastic changes relative to today's atmospheric circulation patterns in response to past climate change (Fig. 2). While ISEA is wet year-around in the modern climate because of its location in the IPWP, this was not the case before the early Holocene. Based on previous proxy studies from the ISEA/IPWP region, the general deglacial climate sequence consists of a cold and dry LGM ( 20 ka BP), followed by further drying during Heinrich Stadial 1 (HS1) (17-15 ka BP), a warmer and more humid Bølling-Allerød (BA) (15-12.8 ka BP), reverting back into the cold and dry Younger Dryas (YD) (12.8-11.7 ka BP), leading into the considerably wetter and warmer Holocene (Fig. 2) (Ayliffe et al., 2013; Partin et al., 2007; Wurtzel et al., 2018). This trend is similar to ice core records on Greenland, indicating that teleconnections between high latitude and tropical 175 climates are important (Yuan et al., 2018). The timing of the driest period is different for records south of the equator, where the southward shifted ITCZ during North Hemisphere $(\mathrm{NH})$ cold events resulted in enhanced Austral-Indonesian summer monsoon precipitation, with relative wetting on the southern hemisphere during YD and HS1 (Ayliffe et al., 2013) (Fig. 2). The general deglacial sequence is however similar, and overall, the implication is that the YD studied here is somewhat less extreme than the LGM but still very distinct from the Holocene. 


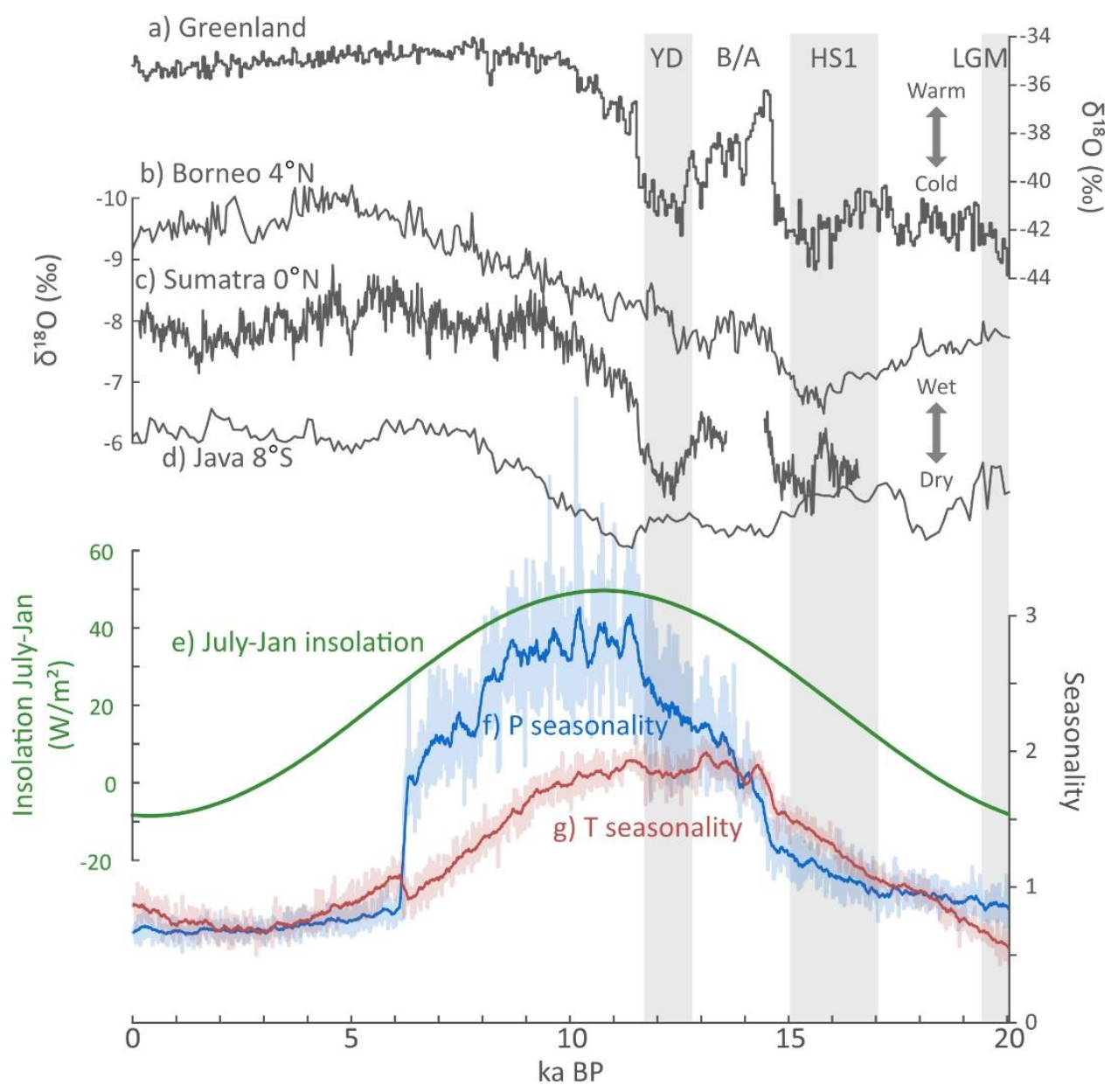

Figure 2: Long-term transient changes in temperature and hydroclimate based on proxy evidence in comparison to seasonality changes in terms of orbital forcing $\left(2^{\circ} \mathbf{N}\right)$ and simulated precipitation $(\mathbf{P})$ and temperature (T). a) Greenland (NGRIP) ice core $\delta^{18} \mathrm{O}$ indicative of northern hemisphere high latitude temperature (NGRIP members, 2004). b, c, and d) speleothem $\delta^{18} \mathrm{O}$, indicative of precipitation amount, from Borneo, Sumatra, and Java in the Sunda region (Partin et al., 2007; Wurtzel et al., 2018; Ayliffe et al., 2013). e) Insolation difference between winter and summer calculated from July minus January insolation from $2{ }^{\circ} \mathrm{N}$ (Laskar et al., 2004). f and g) Seasonality is calculated as JJA/DJF for precipitation (blue) and JJA-DJF for temperature (red) based on the TRACE simulation (He 2011) over Sunda $\left(3^{\circ} \mathrm{S}-1^{\circ} \mathrm{N}, 100^{\circ}-104^{\circ} \mathrm{E}\right)$, with 19 point running mean in bright colors and each data point in pale color. The strong changes in seasonality closely follow the orbital forcing seasonality which is evident in climate model simulations but not visible in the seasonally integrated proxy-signals.

Focusing on $12 \mathrm{ka}$ BP specifically, a compilation of climate and environmental proxy records based on stable isotopes and pollen indicate widespread drier conditions in the Sunda area at $12 \mathrm{ka} \mathrm{BP}$ compared to PI in the region (Fig. 1). However, local deviations are found in some records that do not record a significant change between modern and deglacial climates, notably around Borneo which appears to have remained relatively wet according to proxies (Fig. 1) and climate simulations (Brady et al., 2013). In contrast to a nearby terrestrial speleothem record on Sumatra, Niedermeier et al. (2014) did not find a clear difference over the LGM-Deglaciation-Holocene period in their record based on terrestrial biomarkers found in a marine record 
https://doi.org/10.5194/cp-2021-164

Preprint. Discussion started: 16 December 2021

(c) Author(s) 2021. CC BY 4.0 License.

\section{(c) (1)}

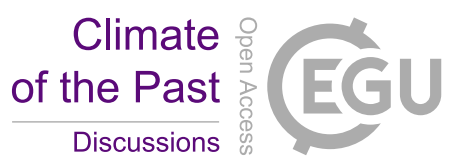

off Sumatra. They attribute this difference to local variations in topography and a different response to sea level rise. Pollen and biomarker records in the southern South China Sea, which mainly receives input from Borneo (Yang et al., 2020), indicate that only small changes in humidity occurred on the Sunda shelf from the LGM to the present (Chabangborn et al., 2018; Hu et al., 2003, 2002; Wang et al., 2007). On the contrary, Yang et al. (2020) found evidence in a nearby marine core for a precipitation minimum during meltwater pulse MWP-1A at $\sim 14 \mathrm{ka}$, and a subsequent slow increase towards the Holocene.

The synthesis of local records suggests an overall drier and/or seasonal climate during the deglacial period including $12 \mathrm{ka} \mathrm{BP,}$ but with some more local ever-wet exceptions, particularly around Borneo. In line with this, large-scale peat formation on the ISEA, which requires ever-wet or water-logged conditions, first initiated in central Borneo (purple in Fig. 1) around 14 ka BP (Dommain et al., 2014). In contrast, almost all other peatlands in the region started to accumulate only relatively recently, during the Holocene, in particular following the mid-Holocene sea level high stand of $+5 \mathrm{~m}$ a.s.l. at $5000 \mathrm{yr}$ BP (Dommain et al., 2014). This indicates that the continuously anoxic, waterlogged conditions required for peat accumulation did not widely occur before that time, implying that (ancient) land areas of ISEA must have experienced significant dryness, at least seasonally, in today's ever wet region with exception of Borneo.

\section{Model simulations for the Deglacial Period}

\subsection{Transient climate evolution since the LGM (TRACE)}

215 Although the transient simulation of annual precipitation over the ISEA region agrees with the overall drier conditions during the deglaciation reflected in proxy-records (Fig. 1), a key factor appears to be an uneven seasonal distribution of total precipitation compared to the present (and to some extend also LGM) (Fig. 2f). Such a seasonality-signal is usually not directly detectable from proxy records. Contrasting the seasonal cycle as difference between summer and winter climate states, the transient TRACE simulation indicates a major shift to a more seasonal climate on central Sunda during the deglacial and early Holocene, both in terms of precipitation and temperature (Fig. 2f-2g). At the present day, the temperature is stable over the year with generally <1 K difference between summer (JJA) and winter (DJF). Precipitation is slightly lower in summer than winter resulting in a precipitation ratio for JJA/DJF near or below 1 (Fig. 2f). At $12 \mathrm{ka} \mathrm{BP}$ however, the temperature seasonality is doubled to $\sim 2 \mathrm{~K}$, and precipitation seasonality is completely reversed, with a much drier DJF and the majority of precipitation falling in NH summer, resulting in JJA/DJF ratio of 2 to 3. This rainfall seasonality strongly follows insolation (orbital precession, the 21 ka cycle), which has previously been observed in Sunda region environmental proxies (Partin et al., 2007; Wurster et al., 2019). The insolation difference between the boreal summer and winter at $2^{\circ} \mathrm{N}$ was at a maximum at $11 \mathrm{ka} \mathrm{BP}$, with a $49.7 \mathrm{~W} / \mathrm{m}^{2}(\sim 13.2 \%)$ stronger insolation in July. Currently, July insolation is $8.4 \mathrm{~W} / \mathrm{m}^{2}(2 \%)$ lower than during January (Fig. 2e). 
230 TRACE seasonality on Sunda at $12 \mathrm{ka}$ BP is also much higher compared to LGM. An important difference between the LGM and $12 \mathrm{ka} \mathrm{BP}$ is that the insolation difference between winter and summer was near a minimum at the LGM and PI, while it was near maximum at $12 \mathrm{ka} \mathrm{BP}$ (Fig. 2e). These seasonal orbital forcing extremes provide an important mechanism for an increase in seasonality towards $12 \mathrm{ka}$ BP or the early Holocene relative to LGM and PI. This implies that a mere focus on annual changes (as reflected by most proxy-records; Bova et al., 2021; Liu et al., 2014), will only yield in an incomplete explanation for the drastic paleo-environmental changes. We further evaluate the $12 \mathrm{ka} \mathrm{BP}$ climate state by analyzing a higher resolution simulation.

\subsection{Highly seasonal hydroclimate in the Sunda region at 12 ka BP (CESM1)}

To gain a more realistic representation of topography, sea level changes and atmospheric deep convection over tropical regions, model simulations focused on $12 \mathrm{ka} \mathrm{BP}$ and PI climate states were done using CESM1.0.5 (Schenk et al., 2018). The simulation of $12 \mathrm{ka} \mathrm{BP}$ generally confirms the proxy-evidence for widespread drier conditions (Fig. 3) as a criterion for the absence of tropical rainforest and peat in favor of savanna in the ISEA/IPWP region. Simulated precipitation for PI shows that most precipitation falls over ISEA land areas, but precipitation over land is strongly reduced at $12 \mathrm{ka} \mathrm{BP}$ and shifted to ocean areas over the Indian and Pacific Oceans. The higher resolution CESM precipitation changes are in general agreement with TRACE but more pronounced drying over land than shown by the coarser-resolved TRACE simulation (not shown).

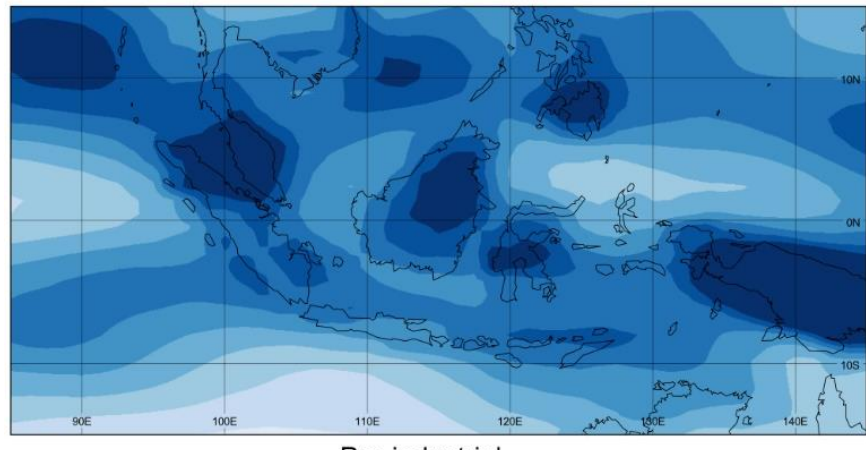

Pre-industrial

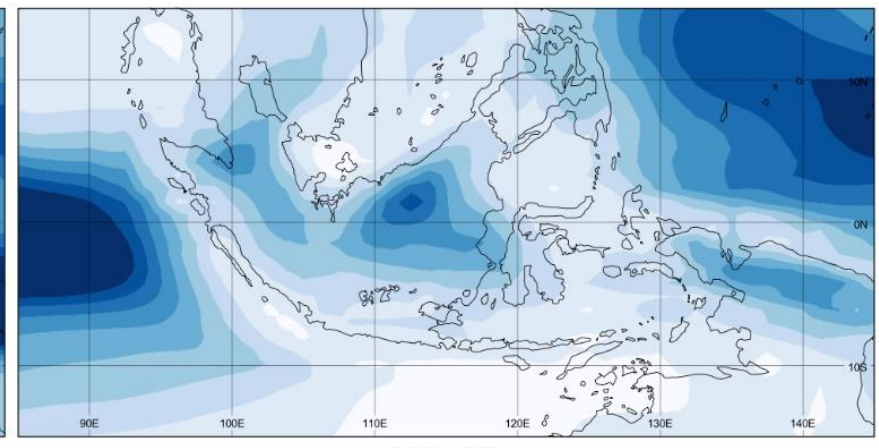

12 ka BP Annual precipitation ( $\mathrm{mm})$

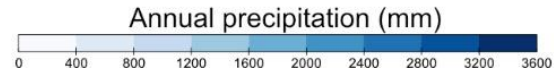

Figure 3. Comparison of annual mean total precipitation (mm/year) at PI and 12 ka BP based on CESM1. The generally drier conditions are consistent with generally drier proxy-evidence during the Deglaciation (e.g. Fig. 2b-d). Note that precipitation at 12 ka BP shifts from the land onto the sea. Seasonal precipitation is shown in Figure S1 with almost no precipitation over most ISEA areas in winter. 
https://doi.org/10.5194/cp-2021-164

Preprint. Discussion started: 16 December 2021

(c) Author(s) 2021. CC BY 4.0 License.

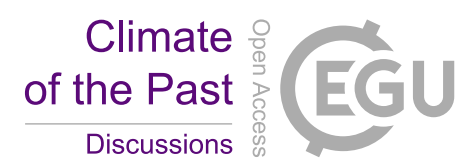

Moreover, our simulations show that the climate was not only drier at $12 \mathrm{ka}$ BP in the Sunda region, but also extremely seasonal with remarkably dry winters, in stark contrast to the PI ever-wet conditions. Figure S1 shows that while all months are generally drier at $12 \mathrm{ka} \mathrm{BP}$ than in PI, the most substantial drying occurs in winters (DJF). By calculating the number of dry months under tropical conditions (defined as $\mathrm{P}<60 \mathrm{~mm} / \mathrm{month}$ ) for each grid point, we find that seasonal droughts were occurring almost everywhere in South-East Asia at $12 \mathrm{ka}$ BP according to our CESM simulation (Fig. 4). Consistent with proxy-evidence (Fig. 1) and TRACE (Fig. 2), this is in stark contrast to the constantly wet PI climate which the entire ISEA and southern mainland SE Asia experiences (Fig. 4 inset). Only central Borneo remained wet throughout the year at $12 \mathrm{ka} \mathrm{BP}$ indicating an exceptional agreement of the simulated spatial precipitation change with proxy evidence and peatland initiation around Borneo (Fig. 1). Apart from Borneo, the dry period duration was approximately 3-4 months in most locations around the equator, 5-7 months for mainland ISEA, and as much as 8-10 months for the Java and the Sahul shelf. That Borneo and the eastern ISEA receives relatively more precipitation, while the rest of Sunda becomes dry during periods of freshwater input into the North Atlantic, as was the case around $12 \mathrm{ka} \mathrm{BP}$, is also supported by freshwater hosing simulations (Mohtadi et al., 2014).
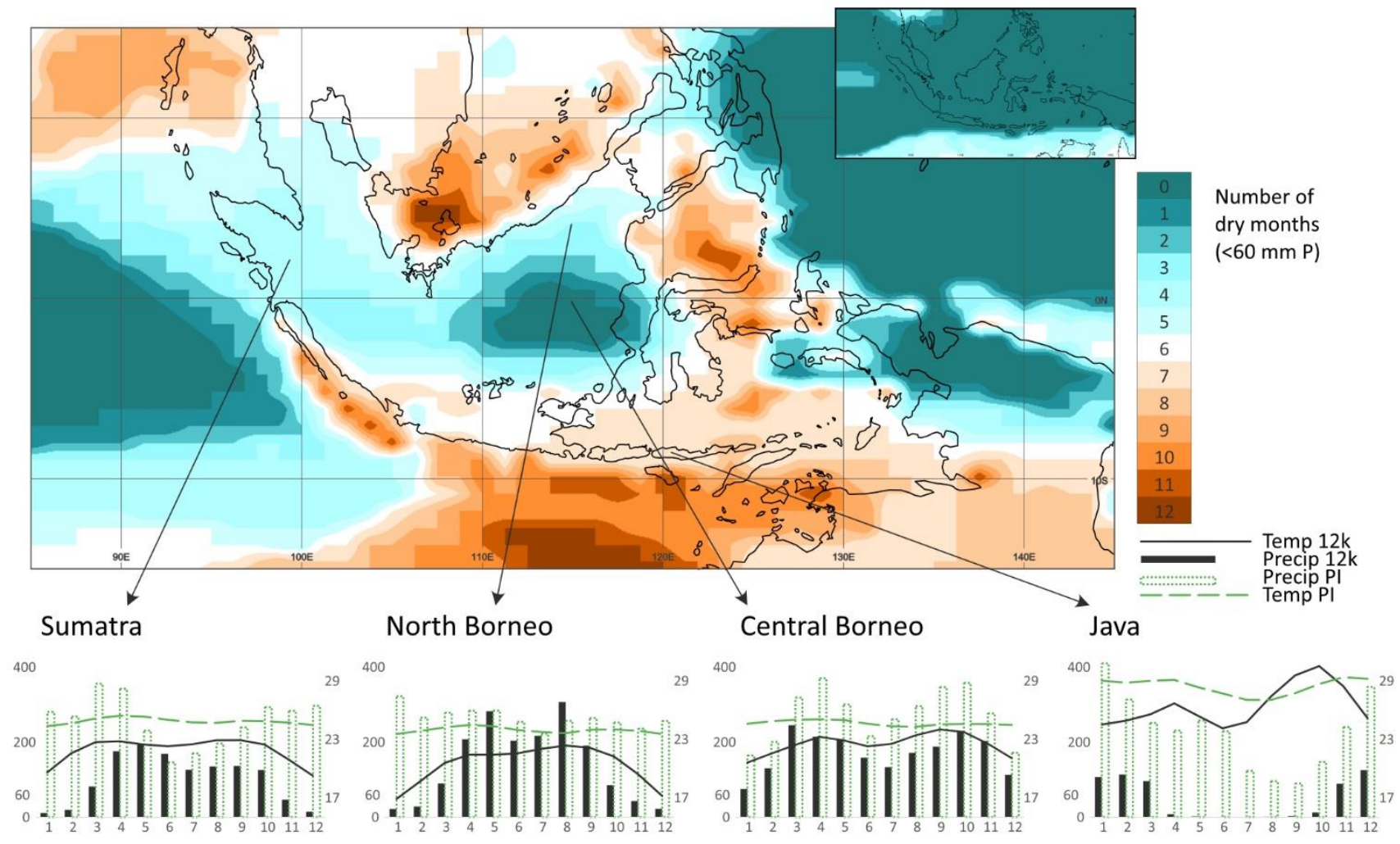

Figure 4: Number of simulated dry months per year at $12 \mathrm{ka}$ BP and comparison of the regional annual temperature and precipitation cycles for 12 ka BP and PI. The inset shows the number of dry months ( $<60 \mathrm{~mm} \mathrm{P} / \mathrm{month})$ per year for PI. Climate diagrams show the monthly average temperature and precipitation from PI (green) and 12 ka BP (black) based on CESM1 simulations. Sumatra, Java and North Borneo locations approximately correspond to speleothem cave locations from the reconstructions in Fig. 2. 
https://doi.org/10.5194/cp-2021-164

Preprint. Discussion started: 16 December 2021

(c) Author(s) 2021. CC BY 4.0 License.

(c) (i)

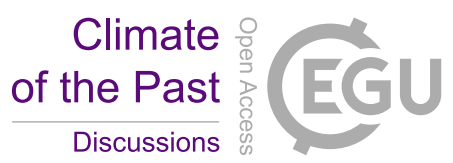

Drastically reduced temperatures are simulated in particular for the exposed, low lying Sunda shelf east of Malaysia and Sumatra, as well as in the highlands of northern Borneo (Fig. S2 and S3). In those areas, TS was down to $\sim 18{ }^{\circ} \mathrm{C}$ in January at $12 \mathrm{ka} \mathrm{BP}$ compared to PI temperatures of around $22^{\circ} \mathrm{C}$ in the highlands to generally $25-27{ }^{\circ} \mathrm{C}$ in most low-lying areas (Fig.

S3). Simulated annual mean ocean temperatures were $\sim 2 \mathrm{~K}$ cooler at $12 \mathrm{ka} \mathrm{BP}$, which is similar to the deglacial cooling proposed in a recent compilation of SST's and thermocline temperatures in ISEA (Dang et al., 2020), but the warming starts earlier according to the proxies. The ocean temperature proxies show peak warmth already at $\sim 10 \mathrm{ka} B P$, and only $\sim 0.5 \mathrm{~K}$ cooler temperature at $12 \mathrm{ka} \mathrm{BP}$ compared to present. This early Holocene warming is inconsistent with most climate models and has been proposed to be related to a seasonal bias of marine proxies known as the 'Holocene Temperature Conundrum' (Bova et al., 2021; Liu et al., 2014). The simulated extreme seasonality changes over tropical land areas provide further evidence for the need to distinguish mean annual changes from the potentially more dominant role of changing seasonality in particular seasonal aridity.

Lower IPWP SST can account for part of the reduced precipitation at $12 \mathrm{ka}$ BP, since a $\sim 7 \%$ decrease in evaporation and

285 subsequent convective precipitation from the ocean can be expected per Kelvin cooling (Clausius-Clapeyron relation). A decrease of around 10-30\% precipitation in January can thus be attributed to the cooling, which falls much short of the total simulated decrease of 50 to $99 \%$ (Fig. S4). We thus conclude that the drastic reduction of winter precipitation compared to PI requires fundamental large-scale changes in terms of atmospheric circulation and cannot be explained alone by a lower moisture availability due to cooling at $12 \mathrm{ka} \mathrm{BP}$.

\subsection{Mechanisms driving strong seasonality in the Sunda region at $12 \mathrm{ka}$ BP}

As outlined in figure 2, transient seasonal insolation changes serve as a good general explanation for seasonal temperature and precipitation changes over ISEA. However, additional changes are required to explain the drastic reductions in seasonal precipitation given the relatively small ocean cooling signal that is insufficient to explain the drastic moisture changes. A key

295 change on hemispheric scale is that mid to high boreal latitudes cooled much more than the tropics at $12 \mathrm{ka}$ BP compared to PI (Fig. S5). This is due to the remaining presence of ice-sheets and sea ice, and the weaker AMOC (He, 2011). NH cooling was then enhanced further in particular during winters due to low orbital winter insolation. Thus, the pole-equator thermal gradient between the IPWP low- and Siberian high-pressure systems, driving the monsoons, was much larger. CESM simulates a $27 \%$ larger (winter) thermal gradient at $12 \mathrm{ka} \mathrm{BP}$ compared to PI between the large land areas of Siberia and Australia $(\Delta \mathrm{T}$

$300=76 \mathrm{~K}$, compared to $60 \mathrm{~K}$ at PI). As a result, CESM simulates a much stronger winter monsoon at $12 \mathrm{ka}$ BP compared to PI (Fig. 5). Such a strengthened winter monsoon is also supported by proxy evidence (Griffiths et al., 2009) and stronger temperature gradients in the South China Sea in the late glacial, both according to SST proxies and the TRACE simulation (Huang et al., 2011; Wen et al., 2016). 
https://doi.org/10.5194/cp-2021-164

Preprint. Discussion started: 16 December 2021

(c) Author(s) 2021. CC BY 4.0 License.

Climate of the Past

Discussions

(c) (i)
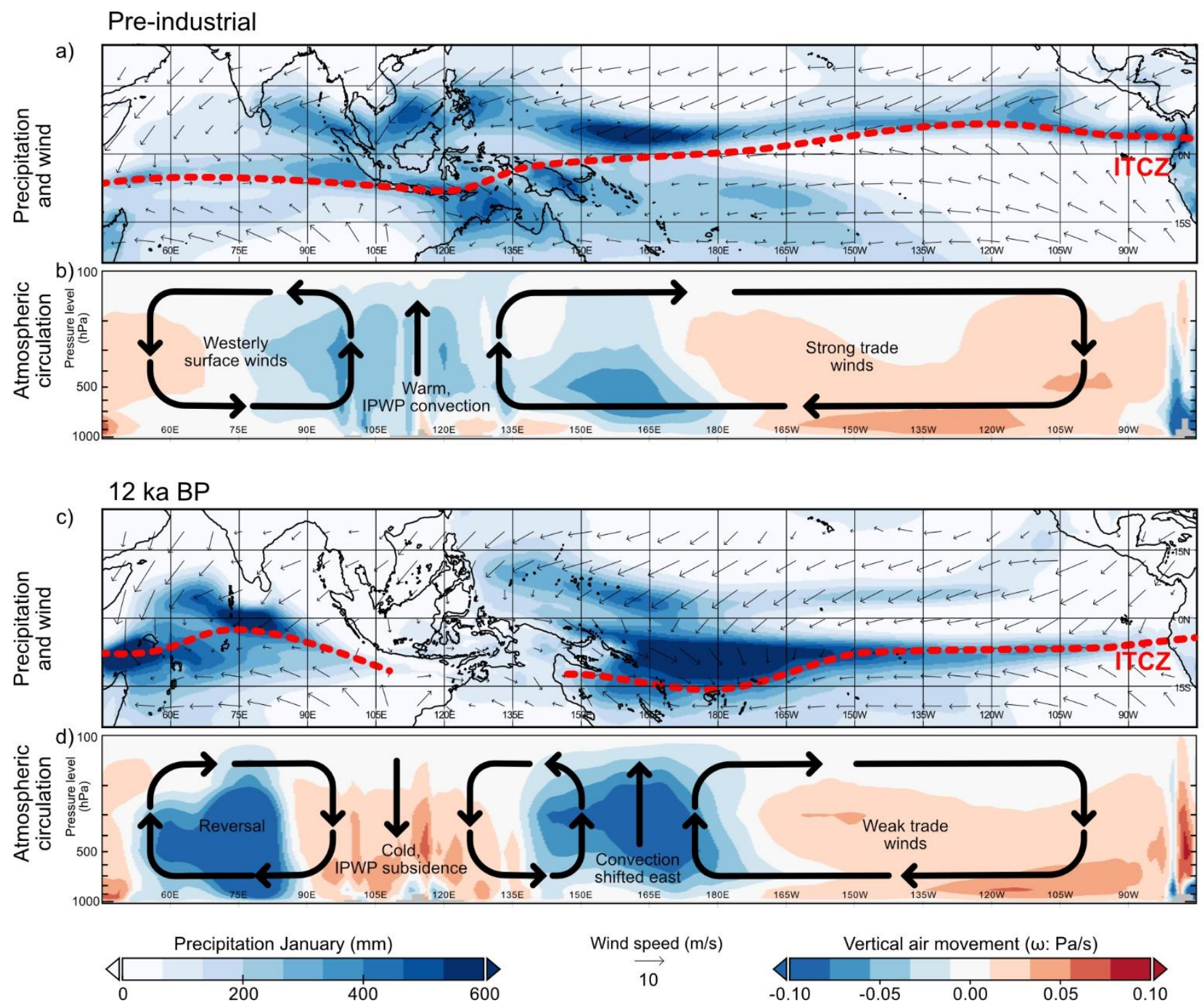

Figure 5. Simplified mechanistic explanation for January precipitation patterns during the pre-industrial (top) and 12 ka BP (bottom) in terms of horizontal and vertical wind patterns. a) and c) show mean total precipitation (mm/month) and surface wind vectors $(\mathrm{m} / \mathrm{s})$ for January; b) and d) Omega parameter $(\omega: \mathrm{Pa} / \mathrm{s})$ representing vertical air movement $(\omega<0$, rising in blue; $\omega>0$ sinking in red) along the equator over the Indo-Pacific region. The approximate January location of the ITCZ and atmospheric Walker Circulation patterns are indicated as red lines $(\mathrm{a}, \mathrm{c})$ and black arrows $(\mathrm{b}, \mathrm{d})$, respectively. Not that the atmospheric circulation cells are inverted over the IPWP region at $12 \mathrm{ka} \mathrm{BP}$ where subsiding air masses, a breakdown of deep convection and divergent winds from land to sea cause seasonal aridity over tropical land areas. 
https://doi.org/10.5194/cp-2021-164

Preprint. Discussion started: 16 December 2021

(c) Author(s) 2021. CC BY 4.0 License.

(c) (i)

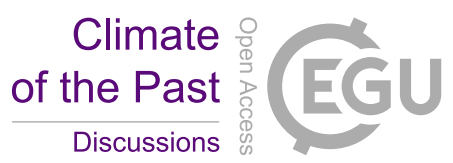

For the pre-industrial simulation, the ITCZ rain bands are present over South-East Asia (Fig. 5a) throughout the year (annual and seasonal precipitation for both simulations are shown in figure 3 and figure S1). Typical PI precipitation for January ranges from 200-500 mm throughout most of ISEA. Precipitation during NH winters is drastically reduced at $12 \mathrm{ka}$ BP with a majority of Sunda receiving <40 mm (Fig. 5) during the driest month, which occurs in January for most locations except Java and Oceania which is driest during July (during the Austral-Indonesian winter monsoon). The rain bands have completely disappeared from the region in the $12 \mathrm{ka} \mathrm{BP}$ simulation during NH winter (Fig. 5c). Over northern Australia and the Sahul shelf, where the Indo-Australian monsoon precipitation peaks during SH summer in January, the precipitation peaks around $440 \mathrm{~mm}$ at PI compared to around $120 \mathrm{~mm}$ at $12 \mathrm{ka} \mathrm{BP}$.

325 Figure 5 also compares the January atmospheric circulation for $12 \mathrm{ka} \mathrm{BP}$ and PI. The large-scale wind pattern with strong convergence over Sunda during the PI leads to deep convection and high precipitation amounts. However, the intrusion of cold and dry northeasterly winds during $12 \mathrm{ka} \mathrm{BP}$, and relatively cold land temperatures over ISEA relative to warmer tropical SST, creates a highly divergent flow over Sunda at $12 \mathrm{ka}$ BP, leading to subsidence and a breakdown of deep convection and seasonal dryness (Fig. 5b, 5d and Fig. 6). Figure 5b and 5d panels represent the vertical component of circulation (Omega parameter; convective, $\omega<0 \mathrm{~Pa} / \mathrm{s}$ ) or sinking (stable, $\omega>0 \mathrm{~Pa} / \mathrm{s}$ ) air masses along a vertical cross-section at the equator for $12 \mathrm{ka} \mathrm{BP}$ and PI that determine the atmospheric circulation cells over Indo-Pacific region. In addition, Fig. 6 displays areas of rising and sinking air masses for both periods on a wider spatial scale around the vertical cross-section in Fig. 5. Deep convection areas are represented by negative $\omega$ values extending beyond the $500 \mathrm{hPa}$ level while local near-surface convection e.g., due to orography, may still occur on the $850 \mathrm{hPa}$ level independent of the large-scale circulation. Both figures clearly

335 show that deep convection over ISEA is drastically reduced or even inverted to into subsidence at $12 \mathrm{ka} \mathrm{BP,} \mathrm{while} \mathrm{convection}$ areas and precipitation is shifted to the oceans. Near-surface ( $850 \mathrm{hPa}$ pressure level) convection still takes place over Borneo and Java in January at $12 \mathrm{ka}$ BP but does not extend further up to higher levels ( $\geq 500 \mathrm{hPa}$ ) in the atmosphere (Fig. 6). Considering convection (Fig. 5b, 5d and Fig. 6), surface winds (Fig. 5a, 5c) and zonal wind patterns (Fig. S6), we sketch the simplified Walker Circulation for both periods in panel $5 \mathrm{~b}$ and $5 \mathrm{~d}$. With the results presented here, CESM1 suggests a 340 breakdown of atmospheric deep convection, drastically reduced precipitation over ISEA and complete re-arrangement of tropical atmospheric circulation over the Pacific and Indian Ocean at $12 \mathrm{ka}$ BP compared to PI. 
$850 \mathrm{hPa}$

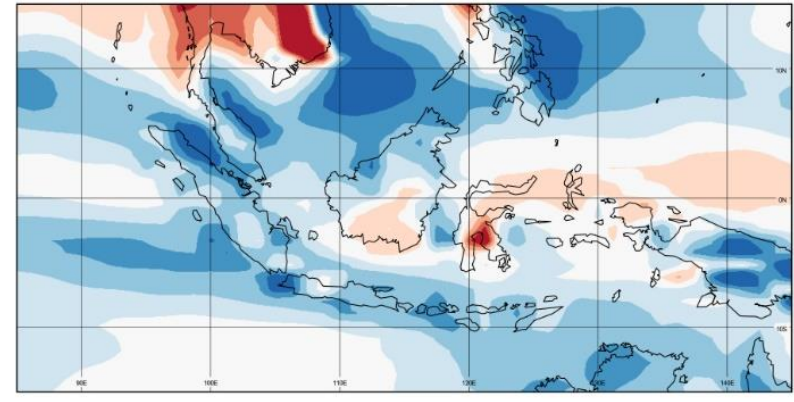

Pre-Industrial

$500 \mathrm{hPa}$

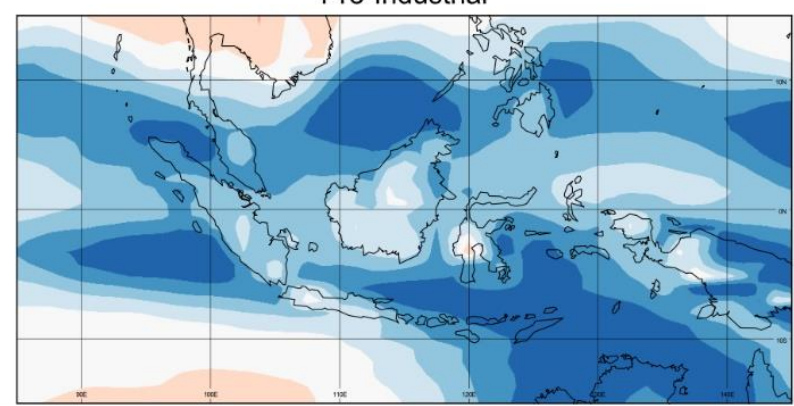

Vertical air movement ( $\omega: \mathrm{Pa} / \mathrm{s})$

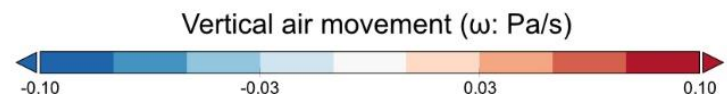

Figure 6. Comparison of near-surface convection/subsidence ( $850 \mathrm{hPa}$ level) with (no) deep convection ( $\geq 500 \mathrm{hPa}$ level) over ISEA during January for PI (left) and 12k (right). As in Fig. 5, negative values (blue) indicate rising air/convection and positive values (red) indicate subsidence/breakdown of convection. Note that near-surface convection due to orography around Borneo at 12 ka BP keeps all months humid (>60 mm) while the overall deep convection of the PI is completely shut down over the whole IPWP region causing at least seasonal aridity.

Overall, the breakdown of deep convection over ISEA also affects the ITCZ and Walker Circulation. The rain bands associated with deep convection over the Pacific and Indian oceans shift south and lose intensity over the Sunda region (Fig. 3), which influences the amount, location and timing of precipitation, thus regulating the seasonality of precipitation and the occurrence of seasonally dry periods. Several lines of evidence from previous research has suggested a southward shift of the ITCZ during the glacial, in particular during Heinrich events or the Younger Dryas (Atwood et al., 2020; Chabangborn et al., 2018; Fraser et al., 2014; McGee et al., 2014; Yang et al., 2020), and this is also simulated by CESM1 (Fig. 5). Main consequences of a southwardly displaced ITCZ are drier and cooler conditions on mainland Asia and consequently a drier and colder East Asian Winter Monsoon (EAWM) (Yang et al., 2020), and wetter conditions on the southern hemisphere (Ayliffe et al., 2013).

In general, the ITCZ mainly responds to NH mean temperature which can be altered on short time scales primarily by Heinrich events, or orbital forcing on longer time scales (Carolin et al., 2016, 2013; Deplazes et al., 2013; Otto-Bliesner and Brady, 2010). The simulated southward shift of the ITCZ and a complete absence of deep convection over ISEA during winter suggest that the ability of the ITCZ in causing rainfall in tropical SE Asia was greatly diminished at $12 \mathrm{ka}$ BP over land areas. As 
https://doi.org/10.5194/cp-2021-164

Preprint. Discussion started: 16 December 2021

(c) Author(s) 2021. CC BY 4.0 License.

\section{(c) (i)}

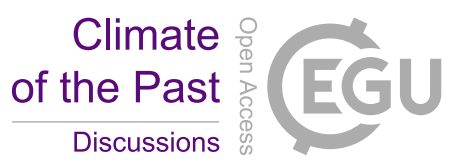

atmospheric deep convection is turned off over land areas of the Sunda region, it is instead shifted east/west into the Pacific Ocean/Indian Ocean (Fig. 5). In winter, this implies a reversal of land-ocean circulation during $12 \mathrm{ka}$ BP causing seasonal aridity. While proxies and models suggest a southward shifted ITCZ and drier and more seasonal conditions, a complete shutdown of deep convection and a dissolution of the ITCZ caused by the cold and dry winter monsoon during NH winter insolation minima, has previously not been suggested.

The shut-down of deep convection over ISEA causes a shift of deep convection to the central Pacific and Indian Ocean, resulting in a completely reorganized Walker Circulation. There is increased precipitation in the western Indian Ocean at 12 ka BP, and a shift to more easterly surface winds (Fig. 5, Fig. S6). The Pacific trade winds were weaker at $12 \mathrm{ka} \mathrm{BP;} \mathrm{the} \mathrm{mean}$ annual wind speeds over the Pacific El Niño region $3.4\left(5^{\circ} \mathrm{N}-5^{\circ} \mathrm{S}, 120-170^{\circ} \mathrm{W}\right)$ were $5.6 \mathrm{~m} / \mathrm{s}$ on average, $12 \%$ weaker than the $6.2 \mathrm{~m} / \mathrm{s}$ annual average for PI. Figure S6 shows the mean zonal winds for $12 \mathrm{ka} \mathrm{BP}$ and PI in January, and indicate a drastic slowdown or reversal of zonal winds over the oceans surrounding ISEA. The zonal SST gradient was also lower at $12 \mathrm{ka} \mathrm{BP}$; the coastal waters west of South America were slightly warmer at $12 \mathrm{ka} \mathrm{BP}$ while the SST in the IPWP was cooler (Fig. S2). An eastward shift of the convective arm of the Pacific Walker Circulation leads to El Niño-like climate conditions that result in a substantial decrease of rainfall in the ISEA region (Dang et al., 2020; De Deckker et al., 2003; DiNezio et al., 2016;

380 Windler et al., 2019).

To put the mean changes of $12 \mathrm{ka}$ BP relative to PI into context with modern ENSO climate states, we compare the monthly Walker Circulation Index (WCI) of the different periods with those to the modern (1979-2020) climate data from the ERA5 reanalysis dataset (Hersbach et al., 2020) in figure 7. The WCI analysis shows that while the Walker Circulation at 12 ka BP

385 was similar in strength in summer compared to PI, it was drastically weaker and even reversed at 12 ka BP during NH winters. In fact, the $12 \mathrm{ka} \mathrm{BP}$ winter Walker Circulation shows the same reversal as the composite average of the most extreme El Niño events of the reanalysis data (in 1983, 1998 and 2015) (Fig. 7). Moreover, the January mean state SST difference at 12 ka BP compared to PI qualitatively replicates the SST anomalies in El Niño events in that the eastern Pacific is anomalously warm compared to the western Pacific (Fig. 7b and 7c). This supports previously hypothesized increased ENSO activity during the deglaciation, based on proxy and model information (Clement et al., 1999; Koutavas and Joanides, 2012; Sadekov et al., 2013), and further suggests that the $12 \mathrm{ka}$ BP mean state resembles modern El Niño conditions in winters. The TRACE winter Walker Circulation is also weakened at $12 \mathrm{ka}$ BP compared to PI, but TRACE very poorly reproduces the observational data and generally shows a too strong circulation and no reversal during $12 \mathrm{ka}$ BP (not shown). This might be an indication that a reversed Walker Circulation in winter at $12 \mathrm{ka}$ BP over ISEA is (at least partly) also due to a more realistic representation of Sunda land exposure and not only due to a southward migration of the ITCZ which is found in both model simulations. 
https://doi.org/10.5194/cp-2021-164

Preprint. Discussion started: 16 December 2021

(c) Author(s) 2021. CC BY 4.0 License.

Climate

Discussions

(c) (i)
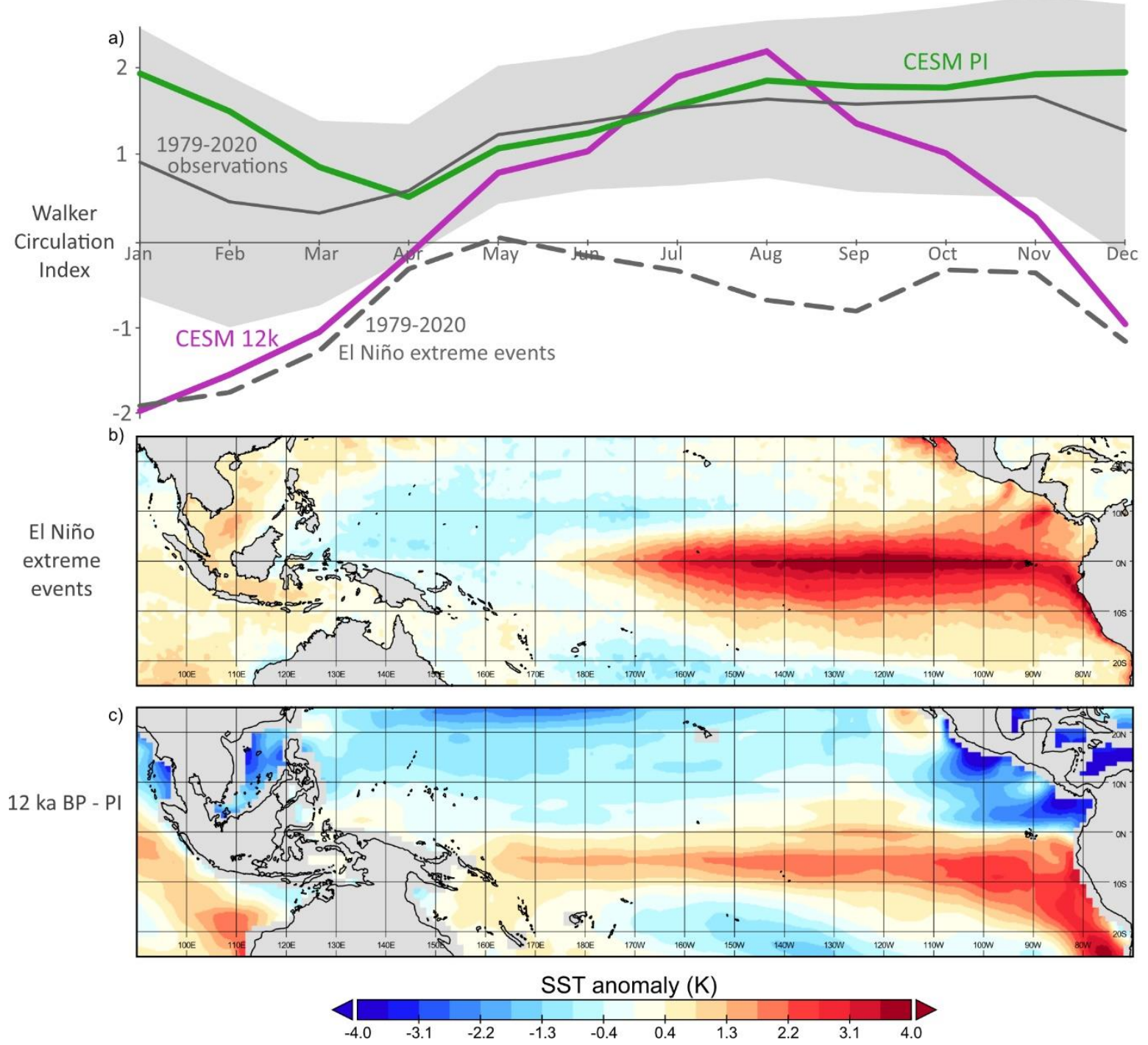

Figure 7. Comparison of the monthly mean Walker Circulation Index and SST anomalies for 12 ka BP and the modern states. a) Monthly mean Walker Circulation Index based on CESM1 simulations for PI (green) and $12 \mathrm{ka}$ BP (purple) and ERA5 reanalysis data for 1979-2020 (gray) with shading denoting \pm 1 standard deviation in ERA5 monthly mean data. Also shown is the composite average over three most extreme El Niño extreme events (dashed gray line) from ERA5 (1983, 1998 and 2015). b) Average SST anomalies for the same three El Niño events, and c) simulated average temperature difference at $12 \mathrm{ka}$ BP compared to PI. The overall global cooling signal averaged over $\pm 23.5^{\circ} \mathrm{N}$ around the equator has been subtracted in c). While the modern SST anomalies represent only extreme El Niño states, spatially comparable El Niño-like conditions dominate the mean climate at $12 \mathrm{ka}$ BP over the tropical Pacific with highly negative Walker Circulation Index values in winter. 
https://doi.org/10.5194/cp-2021-164

Preprint. Discussion started: 16 December 2021

(c) Author(s) 2021. CC BY 4.0 License.

\section{(c) (i)}

Climate
of the Past

Discussions

410

Increased precipitation in the western Indian Ocean combined with the low Sunda precipitation, and strengthened easterly winds over the Indian ocean (Fig. 5), resembles a positive Indian Ocean Dipole (IOD+) state, which has been shown to be caused by Sunda and Sahul shelf exposures during the LGM (DiNezio et al., 2016). This relationship between IOD+ and El Niño-like circulation is in agreement with the IOD dependence on ENSO (Stuecker et al., 2017). This is consistent with the model output for annual precipitation that shows a drier western Pacific and relatively wetter central Pacific (Fig. 5). We therefore conclude that the mean climatic state that governed the tropical IPWP at $12 \mathrm{ka} \mathrm{BP}$ was largely modulated by a major reorganization of the Walker Circulation, resembling permanent El Niño and positive IOD states during NH winters in combination with a stronger winter monsoon and divergent flow over the IPWP region.

Putting our $12 \mathrm{ka} \mathrm{BP}$ results into a wider context, the broken up ITCZ and lower temperatures south of Java and northwest of Australia, amongst the driest places in the simulation, may have been influenced by the lower sea level (DiNezio et al., 2016), but also by reduced heat transport from the Pacific to the Indian Ocean because of the reduced Indonesian Throughflow (ITF; Fig. 1) (Hendrizan et al., 2017). At $6.2 \mathrm{ka}$ BP, the Indonesian Throughflow increased to modern levels in the TRACE simulation leading to a sudden wetting and hence decrease in seasonality (Fig. 2f). This sudden increase in through flow is an artifact of opening an ocean gate way at a low model resolution, and a more realistic representation of ITF opening would be gradual over the early- to mid-Holocene sea level rise. Still, it is clear that the overall effects on Sunda of opened ITF water flow and heat flux are drastically reduced seasonal differences in the region (Fig. 2) via increasing winter precipitation and reducing summer precipitation, as well as the general warming and decrease of insolation seasonality. According to TRACE, the sea level rise-induced opening of the ITF is thus the turning point in seasonality and transition to conditions resembling the present climate. Our CESM1 simulation agrees with earlier coupled climate model simulations of a closed Indonesian Throughflow that suggested an El Niño-like climate mean state (Santoso et al., 2011; Song et al., 2007). An exposed Sunda shelf has earlier been suggested to have suppressed deep atmospheric convection in ISEA during the last glacial period (Bush and Fairbanks, 2003; Chabangborn and Wohlfarth, 2014). Consistent with our results of extreme seasonality, Thirumalai et al. (2019) suggest increased rainfall seasonality caused by the exposure of Sahul and Sunda shelves. Higher albedo of land compared to ocean when the Sunda shelf was exposed has also been proposed to cause lower convection and moisture availability (DiNezio et al., 2016), which may explain part of the precipitation reduction seen in our simulation, since the Sunda shelf was still about $70 \%$ exposed at 12 ka BP (Hanebuth, 2000; Voris and Sathiamurthy, 2006). Reduced heating of the exposed land would have significantly reduced the net energy input to the atmosphere (Byrne and Schneider, 2018) and thus reduced the intensity of ITCZ (DiNezio et al., 2016). Alternatively, the aridity during the last glacial period has been attributed to the exposure of the Sunda shelf that shrunk the Indo-Pacific Warm Pool (Windler et al., 2019). Since the seasonality simulated in TRACE follows insolation, which displays the opposite trend to the initial deglacial sea level rise, we suggest that insolation may have been a more important seasonality driver than sea level in Sunda during the deglaciation, even though precessional cycles may play a smaller role than shelf exposure over longer glacial-interglacial time scales (Windler et al., 2019). 
https://doi.org/10.5194/cp-2021-164

Preprint. Discussion started: 16 December 2021

(C) Author(s) 2021. CC BY 4.0 License.

(c) (i)

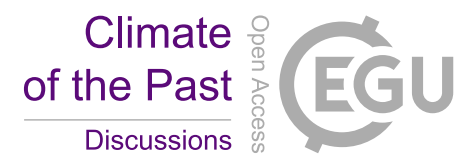

\subsection{Implications for the "Savanna Hypothesis"}

445 The simulated dry winters at $12 \mathrm{ka} \mathrm{BP}$ introduce a dry season in present-day ever-wet locations and/or increase the length of the dry season in other locations (Fig. 4). This must have caused a significant disturbance of the hydrological conditions of many ecosystems, in particular wetlands that could periodically be more prone to drying out. Together with mean annual P of $\sim 1500 \mathrm{~mm}$ in most coastal areas (Fig. 3), the $12 \mathrm{ka} \mathrm{BP}$ climate may in general have favored a savanna biome (Lehmann et al., 2011). The only location that still receives rainfall throughout the year in our simulation ( $>60 \mathrm{~mm} \mathrm{P} / \mathrm{month}$, annual P >2000

$450 \mathrm{~mm}$ ) is Borneo. Together with a minimum monthly surface temperature of $18-23{ }^{\circ} \mathrm{C}$, this provides conditions favorable for ever-wet tropical rainforest vegetation, according to definitions by Köppen and biome reconstructions (Beck et al., 2018; Cannon et al., 2009). The simulated moderate reduction in precipitation on Borneo compared to the rest of Sunda is due to the orographic effect caused by the high mountains on the island, resulting in local near-surface convection and precipitation, despite the large-scale subsidence generally dominating ISEA (Fig. 5 and Fig. 6). Our results are hence also consistent with 455 proxy records around Borneo (Chabangborn et al., 2018; Dubois et al., 2014; Schröder et al., 2018; Wang et al., 2007; Wurster et al., 2019, 2010) and peatland accumulation (Dommain et al., 2014). Dommain et al. (2014) report that the first wetlands to initiate peat accumulation (and are still remaining) in SE Asia were on inland Borneo at approximately 14-15 ka BP. Our simulations show that Borneo was the only location to not experience dry winters during $12 \mathrm{ka} \mathrm{BP}$, giving a possible explanation as to why that was the first location for peat initiation. Furthermore, our results suggest that dry glacial conditions

460 may have lingered on the Sunda shelf until at least $12 \mathrm{ka} \mathrm{BP}$, conditions that may have been suitable for a contiguous Savanna Corridor. While the environmental consequences to our modelling results are not simulated here, and need to be tested using vegetation modelling and further proxy research, the extreme shift in seasonality suggested by our simulations lend a robust modelling support for a Savanna Corridor to be present even during the Late Glacial. Based on the transient simulation of precipitation seasonality of TRACE (Fig. 2f), the combination of an opened Indonesian Throughflow, inundation of Sunda

465 land and a decrease in seasonally diverging orbital forcing (Fig. 2e) may have successively turned ISEA into the ever-wet climate and ecosystem it is today during the early to mid-Holocene. 
https://doi.org/10.5194/cp-2021-164

Preprint. Discussion started: 16 December 2021

(c) Author(s) 2021. CC BY 4.0 License.

\section{(c) (1)}

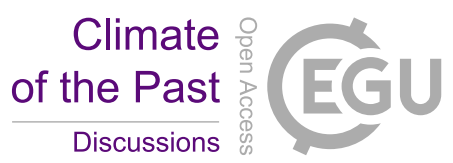

\section{Conclusions}

Using climate simulations for $12 \mathrm{ka} \mathrm{BP}$ and the pre-industrial climate state, a transient simulation from the Last Glacial Maximum to the present, and a proxy compilation from the region, we investigate how the mean climate and its seasonality has changed in Island South East Asia. We particularly focus on the identification of relevant changes and climate mechanisms preventing the establishment of tropical peats and rainforests under glacial and late glacial conditions. Our climate modelling results are in good agreement with proxy-evidence for the generally drier annual conditions that prevailed at $12 \mathrm{ka}$ BP and extended all the way back to the LGM. A more detailed analysis of the source of generally drier conditions highlights that changes during the boreal winter climate were fundamentally different relative to today. Our simulations show that the (hydro)climate was much more seasonal, with the whole region except Borneo experiencing very dry conditions $(<60 \mathrm{~mm}$ monthly precipitation) for several months per year. The spatial pattern of precipitation seasonality agrees well with climate proxies in the region. Notably, CESM1 correctly reproduces ever-wet conditions on Borneo due to local orography-induced convection that provides an explanation for why peat accumulation initiated there, while being impaired elsewhere in the region until the early-mid Holocene.

Key drivers for seasonally dry conditions resulting from differences of the $12 \mathrm{ka}$ BP climate relative to PI consist of 2-3 K colder SST around ISEA - today's heat and moisture engine of the globe - and a 27 \% larger thermal interhemispheric gradient under Late Glacial conditions between Siberia and Australia in boreal winter, driving a stronger winter monsoon. Dry and cold northeasterly winds of the winter monsoon extend far south over today's IPWP region. As a result, winters were dry at $12 \mathrm{ka} \mathrm{BP}$, with a complete collapse of tropical deep convection over ISEA due to diverging winds from land to sea and subsiding air masses over land areas. While lower precipitation due to a southward shift of the ITCZ during (late) glacial conditions has been proposed previously, CESM1 clearly shows that the reversal of the land-sea circulation over ISEA in boreal winter acts as an independent mechanism dissolving any large-scale convergence of a potential ITCZ over land.

In summary, the main reason for the extreme precipitation seasonality changes relate to the suppressed deep convection over ISEA in response to a reduced winter insolation on the northern hemisphere and Sunda shelf exposure that render land areas much colder than the sea around it in boreal winters. This in turn leads to a major reorganization of the Walker circulation with a mean state in winters at $12 \mathrm{ka}$ BP strongly resembling today's extreme El Niño events in the Pacific Ocean, and to a lesser extent positive Indian Ocean Dipole conditions. Using our results as analogues for future climate change in the IPWP, we suggest that the seasonal droughts simulated in the model and indicated by vegetation proxies under enhanced ENSO variability in the late glacial, may provide clues to a future response of the earth system under global warming and projected changes in rainfall variability and ENSO. In particular, the paleo-record underlines the importance of closely tracking climate change with a focus on interhemispheric and seasonal divergence which may introduce seasonal aridity in today's ever-wet ISEA region. 
https://doi.org/10.5194/cp-2021-164

Preprint. Discussion started: 16 December 2021

(c) Author(s) 2021. CC BY 4.0 License.

(c) (1)

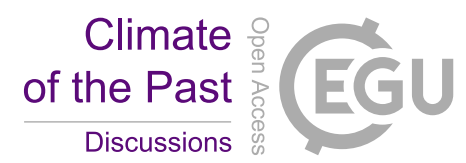

Data availability

The ERA5 data (Hersbach et al., 2019) can be downloaded from the Climate Data Store (CDS) (DOI: 10.24381/cds.f17050d7). CESM1 model data will be made available by Frederik Schenk (frederik.schenk@geo.su.se) upon reasonable request.

\section{Author contributions}

PH and FS designed the study. CESM1 climate model simulations were conducted by FS. XK and PH analyzed the TRACE 505 data. PH created the figures and proxy compilation. PH led the data analysis and PH and FS wrote the manuscript and with contributions from all authors.

\section{Competing interests}

The authors declare that they have no conflict of interest.

\section{Acknowledgements}

510 This research received funding from the Swedish Research Council to F.S. (VR 2015-04418) and R.H.S. (VR 2017-04430) and Swedish Research Council for Sustainable Development to F.S. (FORMAS 2020-01000). X.K. received funding from the National Key Research and Development Program of China under Grant Nos. 2016YFA0600504 and 2017YFA0603803, and the National Natural Science Foundation of China under Grant No. 41775073. The climate model simulations with CESM1 were enabled by resources provided by the Swedish National Infrastructure for Computing (SNIC) at the National

515 Supercomputer Centre (NSC), partially funded by the Swedish Research Council through grant agreement no. 2018-05973. The CESM project is supported by the National Science Foundation and the Office of Science of the U.S. Department of Energy. TRACE was made possible by the DOE INCITE computing program, and supported by NCAR, the NSF P2C2 program, and the DOE Abrupt Change and EaSM programs. 
https://doi.org/10.5194/cp-2021-164

Preprint. Discussion started: 16 December 2021

(c) Author(s) 2021. CC BY 4.0 License.

(c) (i)

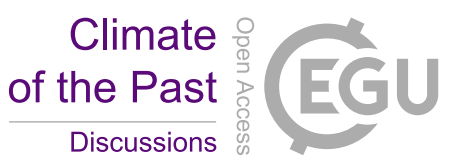

\section{References}

Amante, C. and Eakins, B. W.: ETOPO1 1 Arc-minute global relief model: procedures, data sources and analysis, $25,2009$.

Atwood, A. R., Donohoe, A., Battisti, D. S., Liu, X., and Pausata, F. S. R.: Robust Longitudinally Variable Responses of the ITCZ to a Myriad of Climate Forcings, Geophys. Res. Lett., 47, https://doi.org/10.1029/2020GL088833, 2020.

525 Ayliffe, L. K., Gagan, M. K., Zhao, J., Drysdale, R. N., Hellstrom, J. C., Hantoro, W. S., Griffiths, M. L., Scott-Gagan, H., Pierre, E. S., Cowley, J. A., and Suwargadi, B. W.: Rapid interhemispheric climate links via the Australasian monsoon during the last deglaciation, Nat Commun, 4, 2908, https://doi.org/10.1038/ncomms3908, 2013.

Beck, H. E., Zimmermann, N. E., McVicar, T. R., Vergopolan, N., Berg, A., and Wood, E. F.: Present and future KöppenGeiger climate classification maps at 1-km resolution, Sci Data, 5, 180214, https://doi.org/10.1038/sdata.2018.214, 2018.

530 Bird, M. I., Taylor, D., and Hunt, C.: Palaeoenvironments of insular Southeast Asia during the Last Glacial Period: a savanna corridor in Sundaland?, Quaternary Science Reviews, 24, 2228-2242, https://doi.org/10.1016/j.quascirev.2005.04.004, 2005.

Bova, S., Rosenthal, Y., Liu, Z., Godad, S. P., and Yan, M.: Seasonal origin of the thermal maxima at the Holocene and the last interglacial, 589, 548-553, https://doi.org/10.1038/s41586-020-03155-x, 2021.

Brady, E. C., Otto-Bliesner, B. L., Kay, J. E., and Rosenbloom, N.: Sensitivity to Glacial Forcing in the CCSM4, 26, 19011925, https://doi.org/10.1175/JCLI-D-11-00416.1, 2013.

Bush, A. B. G. and Fairbanks, Richard. G.: Exposing the Sunda shelf: Tropical responses to eustatic sea level change, J. Geophys. Res., 108, 4446, https://doi.org/10.1029/2002JD003027, 2003.

Byrne, M. P. and Schneider, T.: Atmospheric Dynamics Feedback: Concept, Simulations, and Climate Implications, 31, 32493264, https://doi.org/10.1175/JCLI-D-17-0470.1, 2018.

540 Cannon, C. H., Morley, R. J., and Bush, A. B. G.: The current refugial rainforests of Sundaland are unrepresentative of their biogeographic past and highly vulnerable to disturbance, Proceedings of the National Academy of Sciences, 106, 1118811193, https://doi.org/10.1073/pnas.0809865106, 2009.

Carolin, S. A., Cobb, K. M., Adkins, J. F., Clark, B., Conroy, J. L., Lejau, S., Malang, J., and Tuen, A. A.: Varied Response of Western Pacific Hydrology to Climate Forcings over the Last Glacial Period, Science, 340, 1564-1566, https://doi.org/10.1126/science.1233797, 2013.

Carolin, S. A., Cobb, K. M., Lynch-Stieglitz, J., Moerman, J. W., Partin, J. W., Lejau, S., Malang, J., Clark, B., Tuen, A. A., and Adkins, J. F.: Northern Borneo stalagmite records reveal West Pacific hydroclimate across MIS 5 and 6, Earth and Planetary Science Letters, 439, 182-193, https://doi.org/10.1016/j.epsl.2016.01.028, 2016.

Chabangborn, A. and Wohlfarth, B.: Climate over mainland Southeast Asia 10.5-5 ka: CLIMATE OVER MAINLAND SE

ASIA 10.5-5 ka, J. Quaternary Sci., 29, 445-454, https://doi.org/10.1002/jqs.2715, 2014.

Chabangborn, A., Yamoah, K. K. A., Phantuwongraj, S., and Choowong, M.: Climate in Sundaland and Asian monsoon variability during the last deglaciation, Quaternary International, 479, 141-147, https://doi.org/10.1016/j.quaint.2017.04.017, 2018.

Clement, A. C., Seager, R., and Cane, M. A.: Orbital controls on the El Niño/Southern Oscillation and the tropical climate,

Paleoceanography, 14, 441-456, https://doi.org/10.1029/1999PA900013, 1999. 
https://doi.org/10.5194/cp-2021-164

Preprint. Discussion started: 16 December 2021

(c) Author(s) 2021. CC BY 4.0 License.

(c) (i)

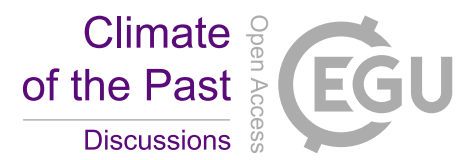

Dang, H., Jian, Z., Wang, Y., Mohtadi, M., Rosenthal, Y., Ye, L., Bassinot, F., and Kuhnt, W.: Pacific warm pool subsurface heat sequestration modulated Walker circulation and ENSO activity during the Holocene, Sci. Adv., 6, eabc0402, https://doi.org/10.1126/sciadv.abc0402, 2020.

De Deckker, P.: The Indo-Pacific Warm Pool: critical to world oceanography and world climate, Geosci. Lett., 3, 20, https://doi.org/10.1186/s40562-016-0054-3, 2016.

De Deckker, P., Tapper, N. J., and van der Kaars, S.: The status of the Indo-Pacific Warm Pool and adjacent land at the Last Glacial Maximum, Global and Planetary Change, 35, 25-35, https://doi.org/10.1016/S0921-8181(02)00089-9, 2003.

Deplazes, G., Lückge, A., Peterson, L. C., Timmermann, A., Hamann, Y., Hughen, K. A., Röhl, U., Laj, C., Cane, M. A., Sigman, D. M., and Haug, G. H.: Links between tropical rainfall and North Atlantic climate during the last glacial period, 6,

213-217, https://doi.org/10.1038/ngeo1712, 2013.

DiNezio, P. N., Timmermann, A., Tierney, J. E., Jin, F., Otto-Bliesner, B., Rosenbloom, N., Mapes, B., Neale, R., Ivanovic, R. F., and Montenegro, A.: The climate response of the Indo-Pacific warm pool to glacial sea level, Paleoceanography, 31, 866-894, https://doi.org/10.1002/2015PA002890, 2016.

Dommain, R., Couwenberg, J., Glaser, P. H., Joosten, H., and Suryadiputra, I. N. N.: Carbon storage and release in Indonesian peatlands since the last deglaciation, Quaternary Science Reviews, 97, 1-32, https://doi.org/10.1016/j.quascirev.2014.05.002, 2014.

Dubois, N., Oppo, D. W., Galy, V. V., Mohtadi, M., van der Kaars, S., Tierney, J. E., Rosenthal, Y., Eglinton, T. I., Lückge, A., and Linsley, B. K.: Indonesian vegetation response to changes in rainfall seasonality over the past 25,000 years, Nature Geosci, 7, 513-517, https://doi.org/10.1038/ngeo2182, 2014.

575 Fraser, N., Kuhnt, W., Holbourn, A., Bolliet, T., Andersen, N., Blanz, T., and Beaufort, L.: Precipitation variability within the West Pacific Warm Pool over the past 120 ka: Evidence from the Davao Gulf, southern Philippines: WPWP precipitation variability, Paleoceanography, 29, 1094-1110, https://doi.org/10.1002/2013PA002599, 2014.

Griffiths, M. L., Drysdale, R. N., Gagan, M. K., Zhao, J. -x., Ayliffe, L. K., Hellstrom, J. C., Hantoro, W. S., Frisia, S., Feng, Y. -x., Cartwright, I., Pierre, E. St., Fischer, M. J., and Suwargadi, B. W.: Increasing Australian-Indonesian monsoon rainfall linked to early Holocene sea-level rise, Nature Geosci, 2, 636-639, https://doi.org/10.1038/ngeo605, 2009.

Grothe, P. R., Cobb, K. M., Liguori, G., Di Lorenzo, E., Capotondi, A., Lu, Y., Cheng, H., Edwards, R. L., Southon, J. R., Santos, G. M., Deocampo, D. M., Lynch-Stieglitz, J., Chen, T., Sayani, H. R., Thompson, D. M., Conroy, J. L., Moore, A. L., Townsend, K., Hagos, M., O'Connor, G., and Toth, L. T.: Enhanced El Niño-Southern Oscillation Variability in Recent Decades, Geophys. Res. Lett., 47, https://doi.org/10.1029/2019GL083906, 2020.

585 Hanebuth, T.: Rapid Flooding of the Sunda Shelf: A Late-Glacial Sea-Level Record, 288, 1033-1035, https://doi.org/10.1126/science.288.5468.1033, 2000.

Hanebuth, T. J. J., Voris, H. K., Yokoyama, Y., Saito, Y., and Okuno, J.: Formation and fate of sedimentary depocentres on Southeast Asia's Sunda Shelf over the past sea-level cycle and biogeographic implications, Earth-Science Reviews, 104, 92110, https://doi.org/10.1016/j.earscirev.2010.09.006, 2011.

$590 \mathrm{He}, \mathrm{F} .:$ Simulating transient climate evolution of the last deglaciation with CCSM3, 2011. 
https://doi.org/10.5194/cp-2021-164

Preprint. Discussion started: 16 December 2021

(c) Author(s) 2021. CC BY 4.0 License.
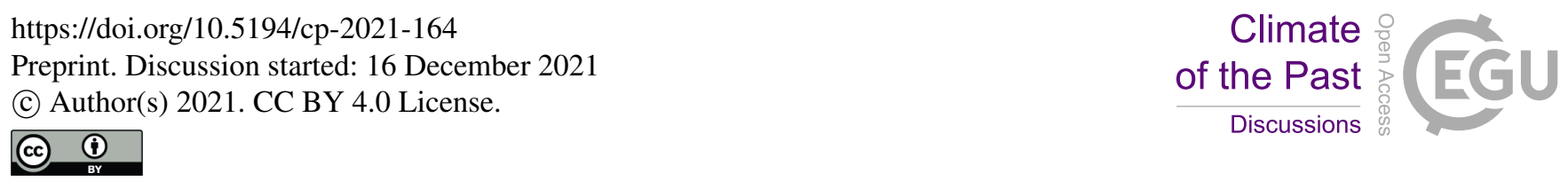

He, F., Shakun, J. D., Clark, P. U., Carlson, A. E., Liu, Z., Otto-Bliesner, B. L., and Kutzbach, J. E.: Northern Hemisphere forcing of Southern Hemisphere climate during the last deglaciation, Nature, 494, 81-85, https://doi.org/10.1038/nature11822, 2013.

Heaney, L. R.: A synopsis of climatic and vegetational change in Southeast Asia, Climatic Change, 19, 53-61, https://doi.org/10.1007/BF00142213, 1991.

Hendrizan, M., Kuhnt, W., and Holbourn, A.: Variability of Indonesian Throughflow and Borneo Runoff During the Last 14 kyr: ITF and Borneo Runoff Over 14 kyr, Paleoceanography, 32, 1054-1069, https://doi.org/10.1002/2016PA003030, 2017.

Hersbach, H., Bell, B., Berrisford, P., Biavati, G., Horányi, A., Muñoz-Sabater, Nicolas, J., Peubey, C., Radu, R., Rozum, I., Schepers, D., and Simmons, A.: ERA5 monthly averaged data on single levels from 1979 to present, https://doi.org/10.24381/CDS.F17050D7, 2019.

Hersbach, H., Bell, B., Berrisford, P., Hirahara, S., Horányi, A., Muñoz-Sabater, J., Nicolas, J., Peubey, C., Radu, R., Schepers, D., Simmons, A., Soci, C., Abdalla, S., Abellan, X., Balsamo, G., Bechtold, P., Biavati, G., Bidlot, J., Bonavita, M., Chiara, G., Dahlgren, P., Dee, D., Diamantakis, M., Dragani, R., Flemming, J., Forbes, R., Fuentes, M., Geer, A., Haimberger, L., Healy, S., Hogan, R. J., Hólm, E., Janisková, M., Keeley, S., Laloyaux, P., Lopez, P., Lupu, C., Radnoti, G., Rosnay, P.,

605 Rozum, I., Vamborg, F., Villaume, S., and Thépaut, J.: The ERA5 global reanalysis, Q.J.R. Meteorol. Soc., 146, 1999-2049, https://doi.org/10.1002/qj.3803, 2020.

Hu, J., Peng, P., Jia, G., Fang, D., Zhang, G., Fu, J., and Wang, P.: Biological markers and their carbon isotopes as an approach to the paleoenvironmental reconstruction of Nansha area, South China Sea, during the last $30 \mathrm{ka}$, Organic Geochemistry, 33, 1197-1204, https://doi.org/10.1016/S0146-6380(02)00082-7, 2002.

610 Hu, J., Peng, P., Fang, D., Jia, G., Jian, Z., and Wang, P.: No aridity in Sunda Land during the Last Glaciation: Evidence from molecular-isotopic stratigraphy of long-chain n-alkanes, Palaeogeography, Palaeoclimatology, Palaeoecology, 201, 269-281, https://doi.org/10.1016/S0031-0182(03)00613-8, 2003.

Huang, E., Tian, J., and Steinke, S.: Millennial-scale dynamics of the winter cold tongue in the southern South China Sea over the past $26 \mathrm{ka}$ and the East Asian winter monsoon, Quat. res., 75, 196-204, https://doi.org/10.1016/j.yqres.2010.08.014, 2011.

615 IPCC: Climate Change 2021: The Physical Science Basis. Contribution of Working Group I to the Sixth Assessment Report of the Intergovernmental Panel on Climate Change, 2021.

Ivanovic, R. F., Gregoire, L. J., Kageyama, M., Roche, D. M., Valdes, P. J., Burke, A., Drummond, R., Peltier, W. R., and Tarasov, L.: Transient climate simulations of the deglaciation 21-9 thousand years before present (version 1) - PMIP4 Core experiment design and boundary conditions, 9, 2563-2587, https://doi.org/10.5194/gmd-9-2563-2016, 2016.

620 Kang, S. M., Xie, S.-P., Shin, Y., Kim, H., Hwang, Y.-T., Stuecker, M. F., Xiang, B., and Hawcroft, M.: Walker circulation response to extratropical radiative forcing, Sci. Adv., 6, eabd3021, https://doi.org/10.1126/sciadv.abd3021, 2020.

Konecky, B., Russell, J., and Bijaksana, S.: Glacial aridity in central Indonesia coeval with intensified monsoon circulation, Earth and Planetary Science Letters, 437, 15-24, https://doi.org/10.1016/j.epsl.2015.12.037, 2016.

Koutavas, A. and Joanides, S.: El Niño-Southern Oscillation extrema in the Holocene and Last Glacial Maximum: ENSO

EXTREMA IN THE HOLOCENE AND LGM, Paleoceanography, 27, https://doi.org/10.1029/2012PA002378, 2012.

Laskar, J., Robutel, P., Joutel, F., Gastineau, M., Correia, A. C. M., and Levrard, B.: A long-term numerical solution for the insolation quantities of the Earth, A\&A, 428, 261-285, https://doi.org/10.1051/0004-6361:20041335, 2004. 
https://doi.org/10.5194/cp-2021-164

Preprint. Discussion started: 16 December 2021

(c) Author(s) 2021. CC BY 4.0 License.
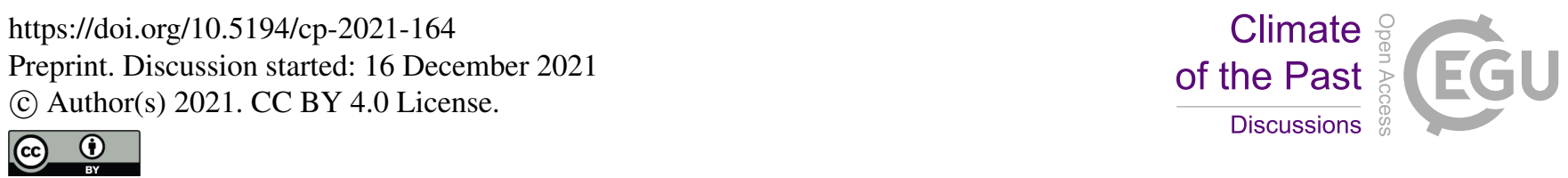

Lehmann, C. E. R., Archibald, S. A., Hoffmann, W. A., and Bond, W. J.: Deciphering the distribution of the savanna biome, New Phytologist, 191, 197-209, https://doi.org/10.1111/j.1469-8137.2011.03689.x, 2011.

630 Liu, Z., Otto-Bliesner, B. L., He, F., Brady, E. C., Tomas, R., Clark, P. U., Carlson, A. E., Lynch-Stieglitz, J., Curry, W., Brook, E., Erickson, D., Jacob, R., Kutzbach, J., and Cheng, J.: Transient Simulation of Last Deglaciation with a New Mechanism for Bølling-Allerød Warming, 325, 6, 2009.

Liu, Z., Zhu, J., Rosenthal, Y., Zhang, X., Otto-Bliesner, B. L., Timmermann, A., Smith, R. S., Lohmann, G., Zheng, W., and Elison Timm, O.: The Holocene temperature conundrum, Proceedings of the National Academy of Sciences, 111, E3501E3505, https://doi.org/10.1073/pnas.1407229111, 2014.

Louys, J. and Roberts, P.: Environmental drivers of megafauna and hominin extinction in Southeast Asia, Nature, 586, 402406, https://doi.org/10.1038/s41586-020-2810-y, 2020.

Malhi, Y. and Wright, J.: Spatial patterns and recent trends in the climate of tropical rainforest regions, Phil. Trans. R. Soc. Lond. B, 359, 311-329, https://doi.org/10.1098/rstb.2003.1433, 2004.

640 McGee, D., Donohoe, A., Marshall, J., and Ferreira, D.: Changes in ITCZ location and cross-equatorial heat transport at the Last Glacial Maximum, Heinrich Stadial 1, and the mid-Holocene, Earth and Planetary Science Letters, 390, 69-79, https://doi.org/10.1016/j.epsl.2013.12.043, 2014.

Mohtadi, M., Prange, M., Oppo, D. W., De Pol-Holz, R., Merkel, U., Zhang, X., Steinke, S., and Lückge, A.: North Atlantic forcing of tropical Indian Ocean climate, Nature, 509, 76-80, https://doi.org/10.1038/nature13196, 2014.

645 NGRIP members: High-resolution record of Northern Hemisphere climate extending into the last interglacial period, Nature, 431, 147-151, https://doi.org/10.1038/nature02805, 2004.

Niedermeyer, E. M., Sessions, A. L., Feakins, S. J., and Mohtadi, M.: Hydroclimate of the western Indo-Pacific Warm Pool during the past 24,000 years, Proc Natl Acad Sci USA, 111, 9402-9406, https://doi.org/10.1073/pnas.1323585111, 2014.

Otto-Bliesner, B. L. and Brady, E. C.: The sensitivity of the climate response to the magnitude and location of freshwater

650 forcing: last glacial maximum experiments, Quaternary Science Reviews, 29, 56-73, https://doi.org/10.1016/j.quascirev.2009.07.004, 2010.

Partin, J. W., Cobb, K. M., Adkins, J. F., Clark, B., and Fernandez, D. P.: Millennial-scale trends in west Pacific warm pool hydrology since the Last Glacial Maximum, Nature, 449, 452-455, https://doi.org/10.1038/nature06164, 2007.

Raes, N., Cannon, C. H., Hijmans, R. J., Piessens, T., Saw, L. G., van Welzen, P. C., and Slik, J. W. F.: Historical distribution 655 of Sundaland's Dipterocarp rainforests at Quaternary glacial maxima, Proc Natl Acad Sci USA, 111, 16790-16795, https://doi.org/10.1073/pnas.1403053111, 2014.

Sadekov, A. Y., Ganeshram, R., Pichevin, L., Berdin, R., McClymont, E., Elderfield, H., and Tudhope, A. W.: Palaeoclimate reconstructions reveal a strong link between El Niño-Southern Oscillation and Tropical Pacific mean state, Nat Commun, 4, 2692, https://doi.org/10.1038/ncomms3692, 2013.

660 Santoso, A., Cai, W., England, M. H., and Phipps, S. J.: The Role of the Indonesian Throughflow on ENSO Dynamics in a Coupled Climate Model, 24, 585-601, https://doi.org/10.1175/2010JCLI3745.1, 2011.

Schenk, F., Muschitiello, Francesco, Tarasov, Lev, Heikkilä, Maija, Björck, Svante, Brandefeld, Jenny, Johansson, Arne V, Näslund, Jens-Ove, and Wohlfarth, Barbara: Warm summers during the Younger Dryas cold reversal, 13, 2018. 
https://doi.org/10.5194/cp-2021-164

Preprint. Discussion started: 16 December 2021

(c) Author(s) 2021. CC BY 4.0 License.

(c) (i)

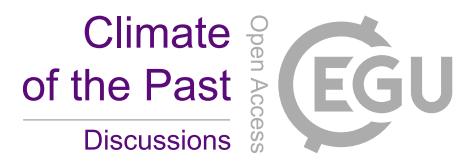

Schröder, J. F., Kuhnt, W., Holbourn, A., Beil, S., Zhang, P., Hendrizan, M., and Xu, J.: Deglacial Warming and Hydroclimate

665 Variability in the Central Indonesian Archipelago, Paleoceanography and Paleoclimatology, 33, 974-993, https://doi.org/10.1029/2018PA003323, 2018.

Song, Q., Vecchi, G. A., and Rosati, A. J.: The Role of the Indonesian Throughflow in the Indo-Pacific Climate Variability in the GFDL Coupled Climate Model, 20, 2434-2451, https://doi.org/10.1175/JCLI4133.1, 2007.

Stuecker, M. F., Timmermann, A., Jin, F., Chikamoto, Y., Zhang, W., Wittenberg, A. T., Widiasih, E., and Zhao, S.: Revisiting

670 ENSO/Indian Ocean Dipole phase relationships, Geophys. Res. Lett., 44, 2481-2492, https://doi.org/10.1002/2016GL072308, 2017.

Thirumalai, K., DiNezio, P. N., Tierney, J. E., Puy, M., and Mohtadi, M.: An El Niño Mode in the Glacial Indian Ocean?, Paleoceanography and Paleoclimatology, 34, 1316-1327, https://doi.org/10.1029/2019PA003669, 2019.

Voris, H. K. and Sathiamurthy, E.: Maps of Holocene Sea level transgression and submerged lakes on the Sunda Shelf, 2006.

675 Wang, X., Sun, X., Wang, P., and Stattegger, K.: A high-resolution history of vegetation and climate history on Sunda Shelf since the last glaciation, SCI CHINA SER D, 50, 75-80, https://doi.org/10.1007/s11430-007-2067-4, 2007.

Wen, X., Liu, Z., Wang, S., Cheng, J., and Zhu, J.: Correlation and anti-correlation of the East Asian summer and winter monsoons during the last 21,000 years, Nat Commun, 7, 11999, https://doi.org/10.1038/ncomms11999, 2016.

Wengel, C., Lee, S.-S., Stuecker, M. F., Timmermann, A., Chu, J.-E., and Schloesser, F.: Future high-resolution El

Niño/Southern Oscillation dynamics, Nat. Clim. Chang., 11, 758-765, https://doi.org/10.1038/s41558-021-01132-4, 2021.

Windler, G., Tierney, J. E., DiNezio, P. N., Gibson, K., and Thunell, R.: Shelf exposure influence on Indo-Pacific Warm Pool climate for the last 450,000 years, Earth and Planetary Science Letters, 516, 66-76, https://doi.org/10.1016/j.eps1.2019.03.038, 2019.

Wurster, C. M., Bird, M. I., Bull, I. D., Creed, F., Bryant, C., Dungait, J. A. J., and Paz, V.: Forest contraction in north 685 equatorial Southeast Asia during the Last Glacial Period, Proceedings of the National Academy of Sciences, 107, 1550815511, https://doi.org/10.1073/pnas.1005507107, 2010.

Wurster, C. M., Rifai, H., Zhou, B., Haig, J., and Bird, M. I.: Savanna in equatorial Borneo during the late Pleistocene, Sci Rep, 9, 6392, https://doi.org/10.1038/s41598-019-42670-4, 2019.

Wurtzel, J. B., Abram, N. J., Lewis, S. C., Bajo, P., Hellstrom, J. C., Troitzsch, U., and Heslop, D.: Tropical Indo-Pacific hydroclimate response to North Atlantic forcing during the last deglaciation as recorded by a speleothem from Sumatra, Indonesia, Earth and Planetary Science Letters, 492, 264-278, https://doi.org/10.1016/j.epsl.2018.04.001, 2018.

Yang, Z., Li, T., Lei, Y., Chang, F., and Nan, Q.: Vegetation evolution-based hydrological climate history since LGM in southern South China Sea, Marine Micropaleontology, 156, 101837, https://doi.org/10.1016/j.marmicro.2020.101837, 2020.

Yuan, X., Kaplan, M. R., and Cane, M. A.: The Interconnected Global Climate System-A Review of Tropical-Polar

Teleconnections, J. Climate, 31, 5765-5792, https://doi.org/10.1175/JCLI-D-16-0637.1, 2018. 